\title{
Exosomes: A rising star in breast cancer (Review)
}

\author{
LINGXIA WANG $^{1 *}$, BO WANG $^{2 *}$, HUIYAN WEN $^{1}$, \\ JIAHUI MAO ${ }^{3}$, YANG REN ${ }^{2}$ and HUAN YANG ${ }^{1}$

\begin{abstract}
Departments of ${ }^{1}$ Clinical Laboratory and ${ }^{2}$ Oncology, The Second Affiliated Hospital of Soochow University, Suzhou, Jiangsu 215004; ${ }^{3}$ Department of Central Laboratory, The Affiliated Hospital of Jiangsu University, Zhenjiang, Jiangsu 212000, P.R. China
\end{abstract}

Received October 28, 2019; Accepted April 24, 2020

DOI: $10.3892 /$ or.2020.7638

\begin{abstract}
Exosomes are nano-sized extracellular vesicles composed of lipid bilayers. They originate from different types of cells and contain various biological molecules. Exosomes can release their contents and exert their corresponding biological functions. In addition, exosomes play important roles in clinical applications. Exosomes and their contents play key roles in the development of breast cancer, including promoting tumorigenesis, metastasis, angiogenesis, immune escape, and treatment resistance. Exosomes can also be used as biomarkers for cancer diagnosis, prognosis and treatment. In this review, we propose that exosomes are important in clinical applications for breast cancer and their roles cannot be neglected.
\end{abstract}

Correspondence to: Professor Huan Yang, Department of Clinical Laboratory, The Second Affiliated Hospital of Soochow University, 1055 Sanxiang Road, Suzhou, Jiangsu 215004, P.R. China

E-mail: zjyhcherry@126.com

*Contributed equally

Abbreviations: miRNAs, micoRNAs; lncRNAs, long non-coding RNAs; TEM, transmission electron microscopy; SEM, scanning electron microscopy; AFM, atomic force microscopy; NTA, nanoparticle tracking analysis; FACS, fluorescence activating cell sorter; -EMT, epithelial-mesenchymal transition; MSC, mesenchymal stem cell; HUVECs, human umbilical vein endothelial cells; MDSCs, myeloid-derived suppressor cells; CAF, cancer-associated fibroblasts; VEGF, vascular endothelial growth factor; mtDNA, mitochondrial DNA; HT, hormonal-therapy; TAMs, tumor-associated macrophages; MBC, metastatic breast cancer; LBC, localized breast cancer; TNBC, triple-negative breast cancer; Del-1, developmentally regulated endothelial locus 1; EGFR, epidermal growth factor receptor; HCC70, human breast ductal carcinoma cells; DCIS, ductal carcinoma in situ

Key words: exosomes, exosomal contents, breast cancer, biomarker, tumor microenvironment

\section{Contents}

\section{Introduction}

2. Production, separation and detection of exosomes in breast cancer

3. The functions and mechanisms of exosomes in breast cancer

4. Tumorigenesis

5. Tumor growth, apoptosis and dormancy

6. Tumor metastasis

7. Tumor angiogenesis

8. Tumor thrombosis

9. Tumor autophagy

10. Tumor immune reaction

11. Tumor treatment resistance

12. Differentiation and dedifferentiation of cells in the microenvironment

13. Exosomes as biomarkers in breast cancer

14. Exosomes in breast cancer therapy

15. Exosomes and other diseases

16. Obstacles and future outlook

\section{Introduction}

Breast cancer is the most common type of cancer among women worldwide (1). Despite significant advances in early detection and treatment, breast cancer remains the second leading cause of cancer-related deaths in women (2). The 5 -year survival rate for women with early-stage breast cancer is significantly higher than in those with advanced-stage invasive breast cancer (IBC) (1). Metastasis and recurrence of breast cancer are mainly responsible for the failure of final treatment and the mortality of patients (1). Therefore, it is still difficult to accurately predict the treatment outcome of each patient; thus finding new markers for early diagnosis and prognosis and developing strategies to prevent recurrence and to control metastatic disease is important (3).

In the past decade, the study of exosomes has become more mature. These nano-sized vesicles can be secreted by various types of cells. The diameter of exosomes is $30-150 \mathrm{~nm}(4,5)$. The membranes of exosomes, which can fuse with cell membranes to transport content, are similar to cell membranes (6). The exosomes contain different 
biological molecules, such as nucleic acids, proteins and lipids. Exosomes can mediate the transport of these substances to achieve intercellular communication in physiological and pathological states $(7,8)$. The contents of exosomes reflect the characteristics of parental cells. Under the protection of the lipid bilayer structure, the contents of exosomes can avoid degradation by various enzymes in the blood, and thus be stable in body fluids such as blood, tissue fluid, urine, saliva and intercellular fluid (9-12). These unique characteristics make exosomes reliable biomarkers. Increasing evidence suggests that exosomes play critical roles in tumorigenesis, tumor growth, metastasis, and therapy resistance (13). Exosomal contents have begun to be used in cancer diagnosis and prognosis. In this review, the mechanism and clinical value of exosomes in the development of breast cancer were examined.

\section{Production, separation and detection of exosomes in breast cancer}

Numerous types of cells can secrete exosomes under normal and pathological conditions. Exosomes are mainly derived from the polyvesicles formed by the intracellular lysosomal microsome invagination, which are released into the extracellular matrix after fusion of their extracellular membranes with those of the polyvesicles (13). GTPases (Rab GTPase), intercellular $\mathrm{pH}, \mathrm{p} 53$ regulatory protein tumor suppressor activation pathway 6 (TSAP6), heparanase, psoralen (14) and other enzymes can act as modulators of the secretion of exosomes (13).

Exosomes can be separated from cells or body fluid supernatants by various methods, including ultracentrifugal precipitation, ultrafiltration centrifugal precipitation, sucrose density gradient centrifugal precipitation, immunoaffinity-based capture, and commercial kit precipitation (13). Several new methods have recently emerged, including nanomembrane filtration, antibody-coated magnetic bead separation, and microfluidic immunoaffinity separation methods. Among them, the commercial kit precipitation can quickly separate and increase the recovery of exogenous substances (13).

Biotechniques, which have been used to detect isolated exosomes include transmission electron microscopy (TEM), scanning electron microscopy (SEM), atomic force microscopy (AFM), cryo-TEM, the nanosight system, fluorescence-activated cell sorting (FACS), and western blotting. SEM, TEM and cryo-TEM can usually be used to identify the size of exosomes and distinguish them from other extracellular vesicles. NTA (Nanoparticle tracking analysis) can monitor and quantify particle size, concentration and relative strength in real time. Western blotting and FACS can be used to identify exosomal surface markers. Microarray and high-throughput sequencing techniques accurately detect the relative expression of nucleic acid (15). QuantStudio 3D digital polymerase chain reaction can accurately quantify the expression of miRNAs (15). LC-MS/MS (liquid chromatography/tandem mass spectrometry), western blotting and enzyme linked immunosorbent assay can be used to screen and identify exosomal proteins (16). Integrated magneto-electrochemical analysis is a fast and on-site method for detecting the protein profile in exosomes. The sensitivity and speed have been demonstrated to be superior than those of traditional methods (16).

\section{The functions and mechanisms of exosomes in breast cancer}

Breast cancer-derived exosomes play numerous roles in cell-to-cell and cell-to-microenvironment interactions (summarized in Table I). Examples of exosomal contents participating in the development of breast cancer and their known roles are presented in Figs. 1-3.

Exosomes contain miRNAs, IncRNAs and proteins released from breast cancer cells into target cells, such as other breast cancer cells or normal mammary epithelial cells. The contents of breast cancer cells have been revealed to lead to cell proliferation, invasion and drug resistance $(38,54,63,64,67,68,72,73,75)$, while in normal mammary epithelial cells, they may promote the transformation of normal cells into breast cancer cells (34). In addition, exosomal contents may result in autophagy of normal epithelial cells (76).

The exosomes released from breast cancer cells can act on vascular endothelial cells, leading to endothelial cell necrosis and migration of intravascular cancer cells (59-60). Moreover, exosomes can also be delivered to EPCs (endothelial progenitor cells) and prevent EPC from differentiating into normal vascular endothelial cells, which may cause thrombosis (28). In addition, exosomes in myeloid-derived suppressor cells (MDSCs) can also enter the endothelial cells of blood vessels and promote the angiogenesis of breast cancer (30).

Exosomes transferred from breast cancer cells into macrophages may activate $\mathrm{NF}-\kappa \mathrm{B}$, release cytokines and stimulate autoimmune regulation (29). Exosomes from breast cancer cells also play a role in mesenchymal stem cells (MSCs), thus promoting the differentiation into fibroblasts (36). Conversely, exosomes derived from MSCs can also act on breast cancer cells, leading to dormancy of breast cancer cells (47).

\section{Tumorigenesis}

Tumorigenesis is a qualitative process in tumor development, which determines the existence and absence of tumors. Breast cancer-derived exosomes can promote tumorigenesis in normal mammary epithelial cells by inducing production of cancer cell growth-promoting factors which are helpful in producing a microenvironment that allows tumor growth (76). In addition, miRNA (miR)-21 and miR-10b in exosomes of breast cancer cells and serum of patients have been revealed to instigate non-tumorigenic epithelial cells to form tumors through a dicer-dependent mechanism by targeting phosphatase and tension homolog deleted on chromosome ten (PTEN) and Homeobox D10 ( HOXD10) respectively (34). Exosomal miR-100 has been demonstrated to offset the effects of transcription factors that are induced by epithelial-mesenchymal transition (EMT) and regulate genes involved in tumorigenesis directly (27).

\section{Tumor growth, apoptosis and dormancy}

Tumor growth, apoptosis and dormancy play an important role in the progression of breast cancer. For example, 


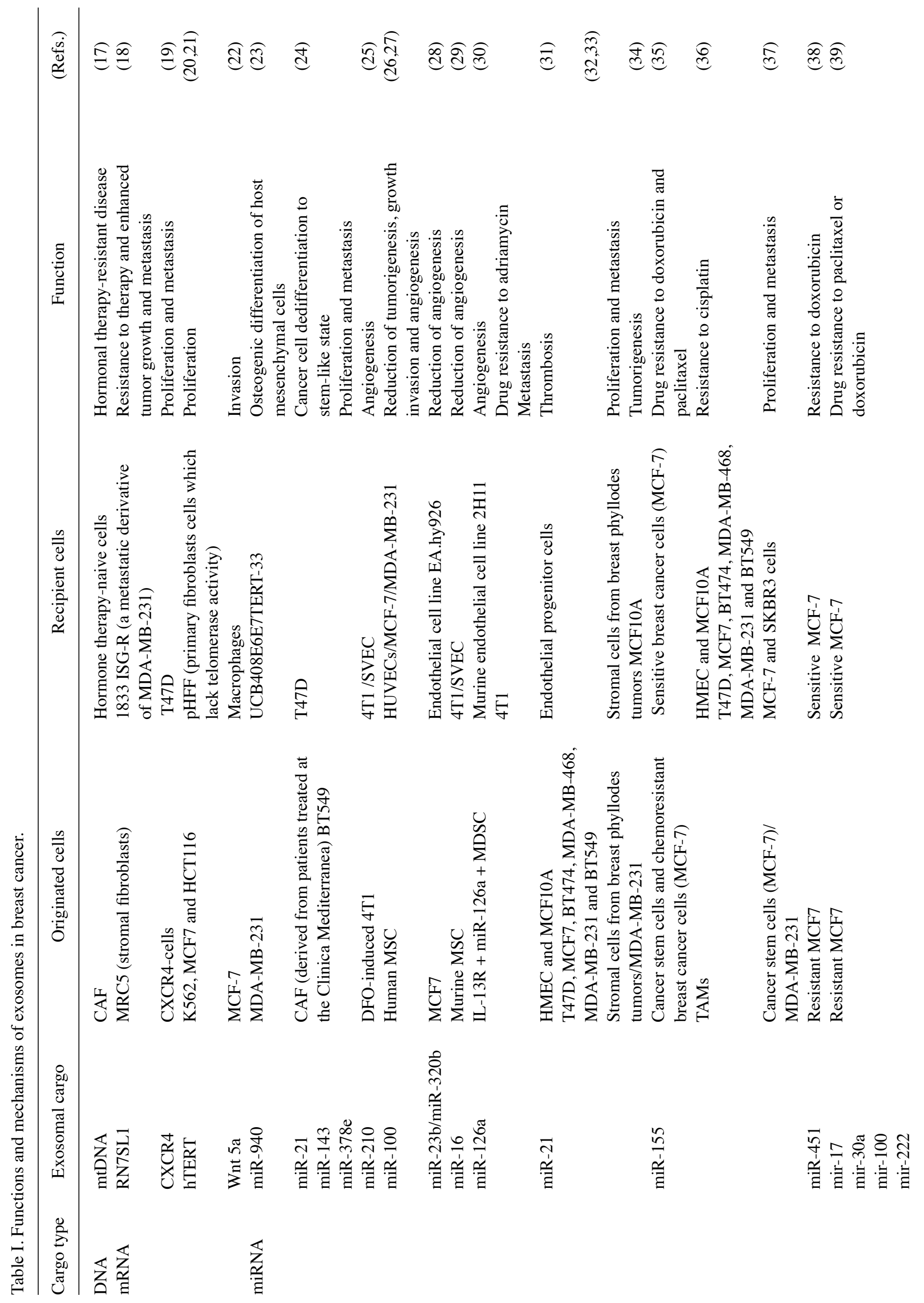




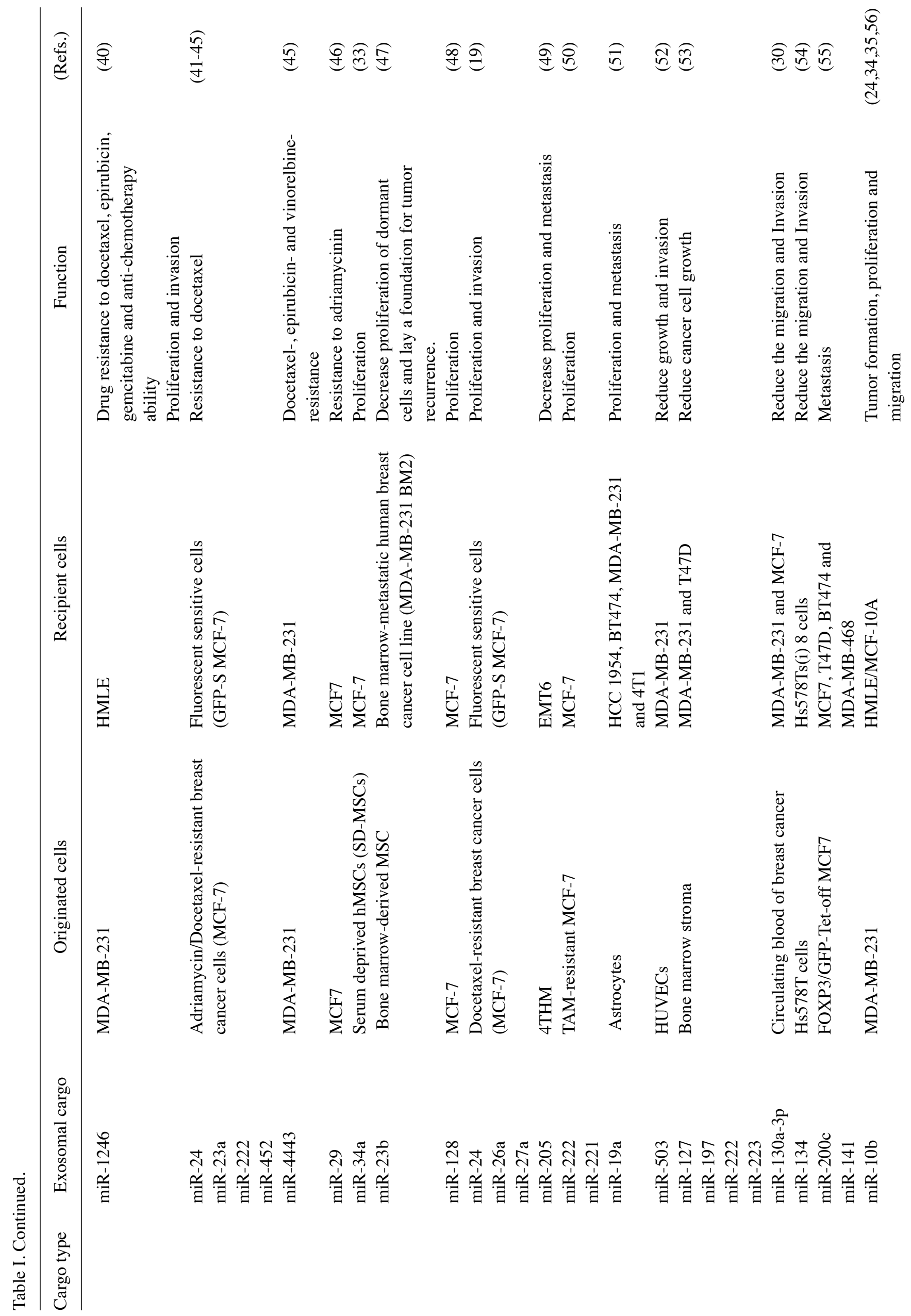




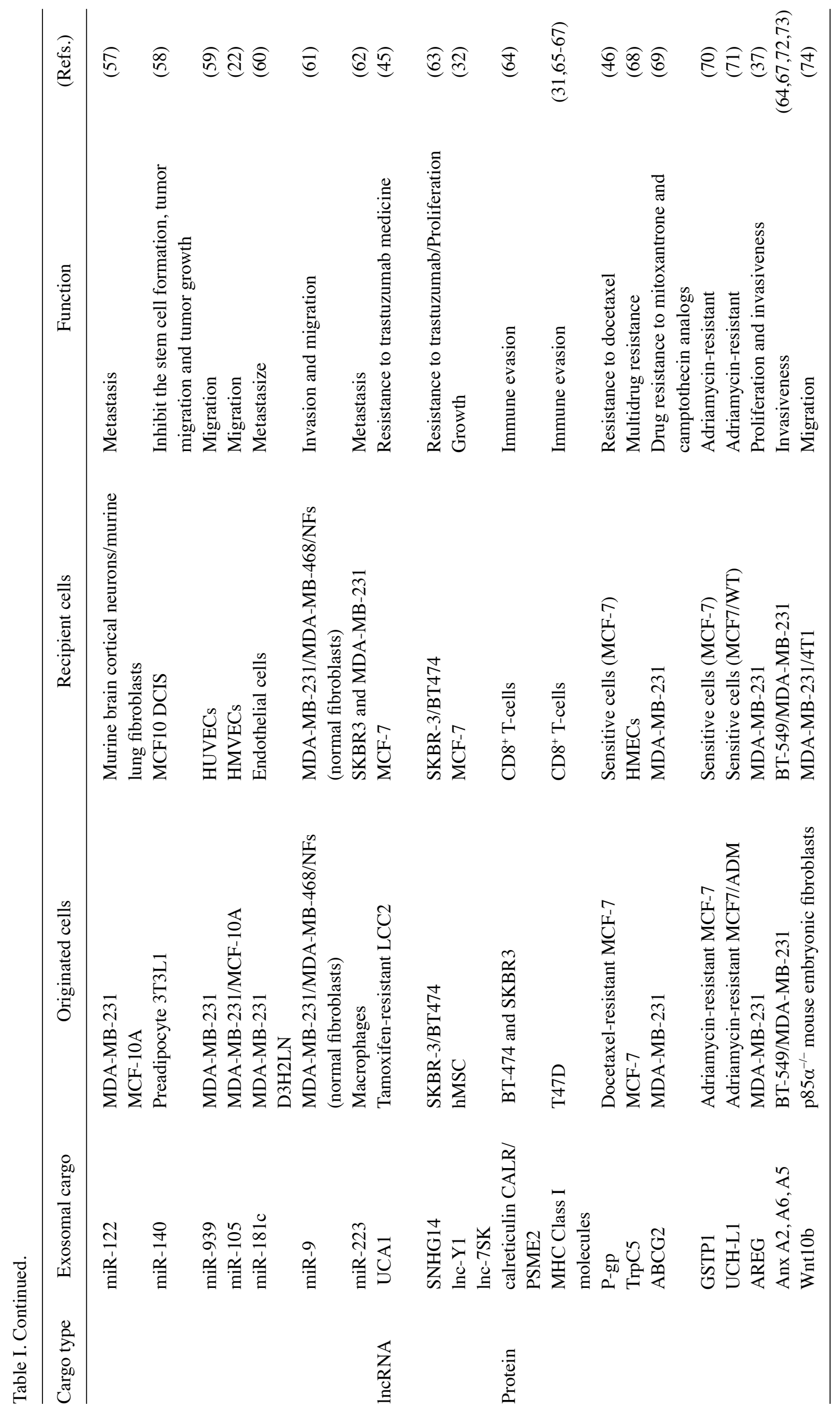



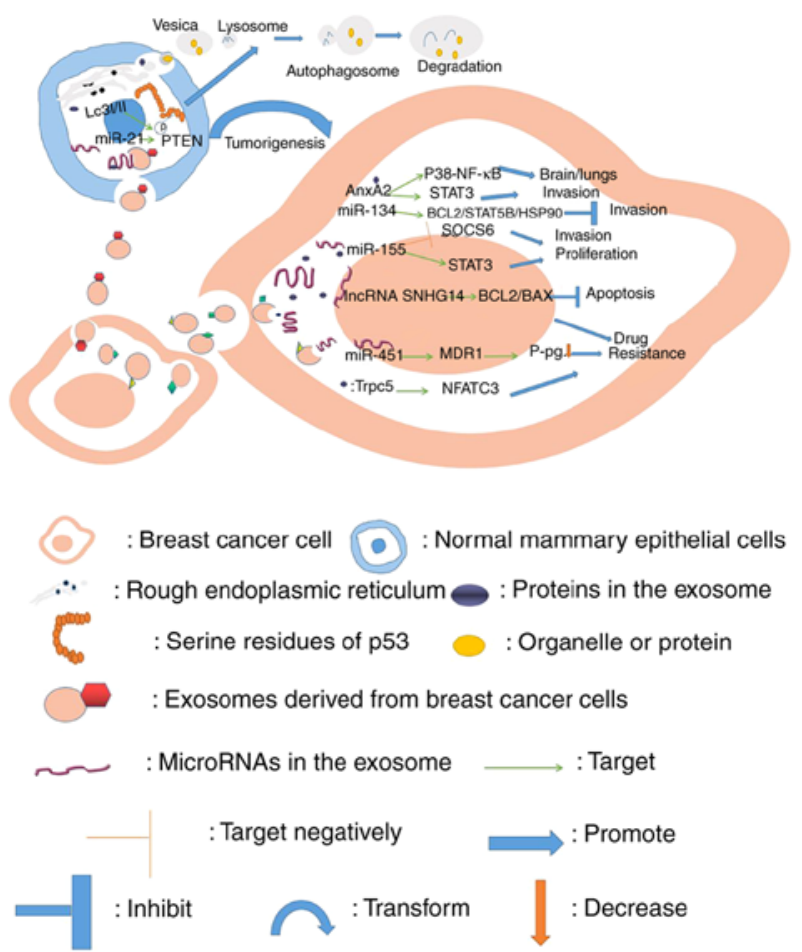

Figure 1. Roles of exosomes in breast cells.
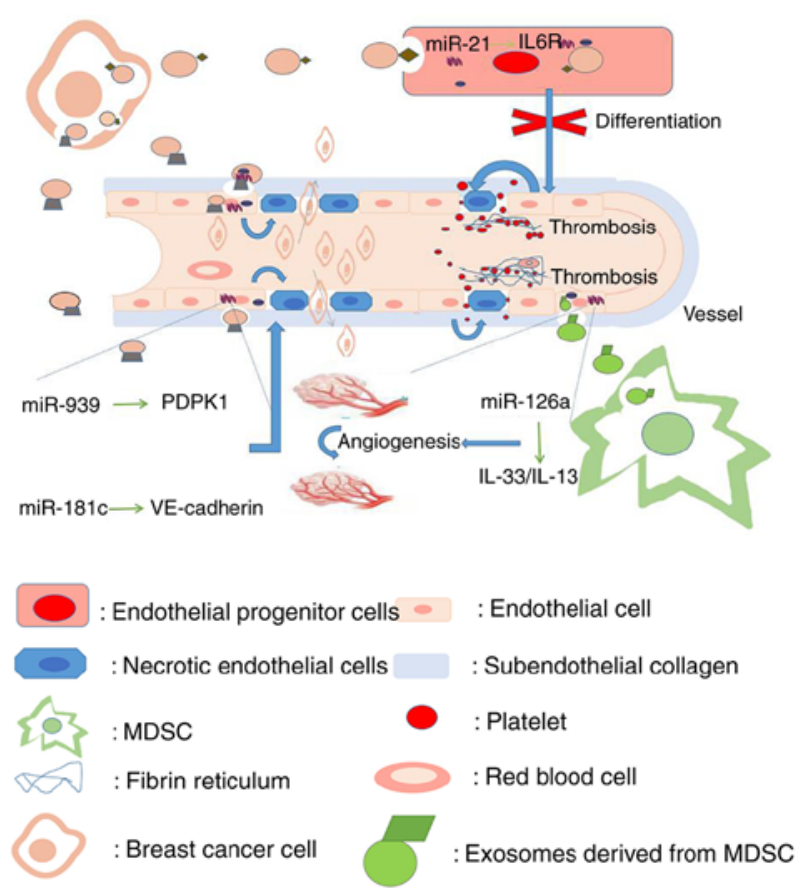

Figure 2. Effects of exosomes on blood vessels of breast cancer.

breast cancer cell-derived exosomal miR-128 was revealed to promote proliferation of MCF-7 cells by targeting the BAX gene (48). miR-10b in exosomes of breast cancer was revealed to target HOXD10 and lead to breast tumor proliferation (24). Additionally, docetaxel-resistant miRNAs (miR-24, miR-26a, and miR-27a) in exosomes are thought to activate the mitogen-activated protein kinase (MAPK) signaling pathway, and have been revealed to be involved in breast

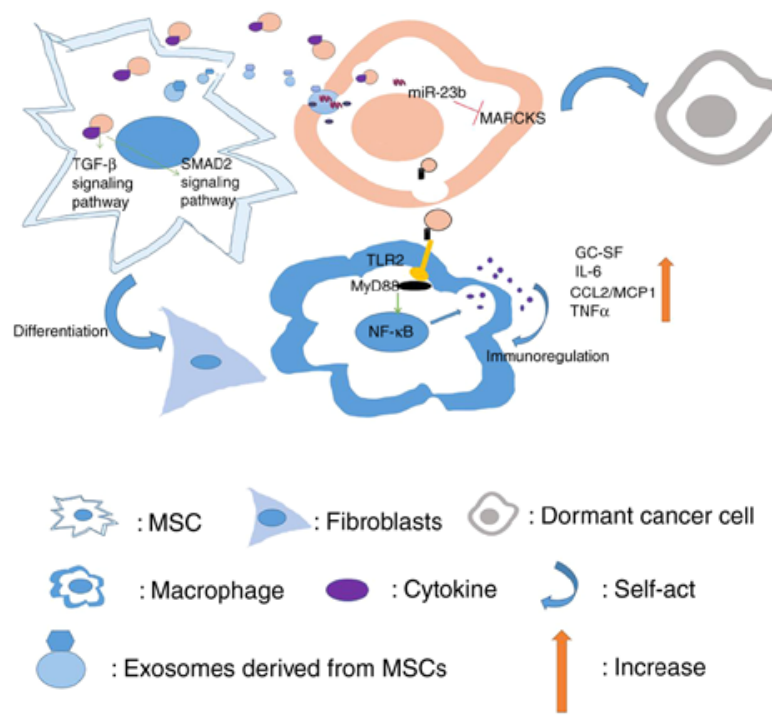

Figure 3. Roles of exosomes between breast cancer cells and other stromal cells.

cancer proliferation (19). miR-1246 was also revealed to be significantly increased in breast cancer cells, especially in MDA-MB-231 exosomes, and could be transferred to target cyclin G2 (CCNG2) directly, leading to cell proliferation (49). Exosomal miR-155 in breast cancer may also promote proliferation of breast cancer cells by inhibiting suppressor of cytokine signaling 6 (SOCS6) and activating signal transducer and activator of transcription 3 (STAT3) (75). Non-coding RNA can also promote cell proliferation. Exosomal long non-coding RNA (lncRNA) UCA1 was revealed to produce AKT/mammalian target of rapamycin (mTOR) signaling (77), leading to increased proliferation of breast cancer cells (40). While the proliferation of cancer cells increases, some molecules can also inhibit apoptosis. For example, exosomes derived from tamoxifen-resistant MCF-7 cells were revealed to carry miR-222 and miR-221, act on parental MCF-7 cells, and reduce the expression of p27 and ERa (estrogen receptor $\alpha$ ) in target cells. The proliferation and the cell cloning ability of sensitive breast cancer cells was enhanced, while the apoptotic ability was weakened (50). IncRNA SNHG14 in exosomes was also revealed to inhibit apoptosis of breast cancer cells via the Bcl-2/Bax pathway (63).

In addition to the exosomes involved in the communication between cancer cells, the exosomes derived from cancer cells can also participate in shaping the microenvironment, thus affecting proliferation of breast cancer. Exosomes from MCF-7 breast cancer contain human telomerase reverse transcriptase (hTERT) mRNA that can be translated into a fully active telomerase enzyme that can promote proliferation in recipient telomerase-negative fibroblasts (78). Exosomal miR-21 was revealed to lead to activation of NF- $\mathrm{KB}$ and promote the proliferation of stromal cells in breast phyllodes tumors (79).

Exosomes from microenvironment cells and non-tumor cells may have a similar role in breast cancer cells. Upon exosome transfer from tumor fibroblasts to breast cancer cells, unshielded RN7SL1 may produce enhanced tumor growth (20). The expression of miR-21 and miR-34a in MSC-derived exosomes has been revealed to be high. Among them, miR-34a was demonstrated to target transcription factor 
E2F3. This microenvironment was beneficial to the growth and survival of breast cancer cells (32). In addition, exosomal miR-34a has been revealed to target tropomyosin alpha-1 chain (TPM1), programmed cell death protein 4 (PDCD4), and Bcl-2 (32,33,80-82). Exosomal miR-19a from astrocytes which leads to PTEN loss may induce chemokine CC ligand (CCL) 2 secretion, leading to brain metastasis outgrowth by promoting metastatic breast cancer (MBC) cells, and inhibiting apoptosis (51). Expression of lnc-Y1 and lnc-7SK derived from MSC exosomes has been revealed to be high and this microenvironment was beneficial to the growth of breast cancer cells (32).

However, certain other exosomes inhibit the proliferation of breast cancer cells. On the one hand, some of these exosomes can act as tumor suppressor genes, thereby inhibiting cancer cell proliferation. On the other hand, some exosomes appear to inhibit cell proliferation, but they are actually dormant cells, thus laying the foundation for cancer cell resuscitation.

Bone marrow MSC-derived exosomal miR-100 may reduce growth of breast cancer by directly targeting HOXA1 (27). Human umbilical vein endothelial cells (HUVECs) were revealed to be capable of transmitting miR-503 to breast tumor cells via exosomes and then reduce cancer cell growth by targeting cyclin D2 (CCND2) and cyclin D3 (CCND3) (52). It can be inferred that these exosomes can be used to treat cancer. Nevertheless, the bone marrow MSC-derived miR-23b was revealed to be transferred into breast cancer cells through exosomes, inhibit MARCKS (a protein involved in the promotion of cell cycling) and decrease proliferation of dormant cells, thereby laying a foundation for tumor recurrence (47). Lim et al reported that exosomal miR-127, miR-197, miR-222 and miR-223 released from bone marrow stromal cells negatively promoted breast cancer cell growth by targeting CXCL12, resulting in induction of dormancy of breast cancer cells (53).

\section{Tumor metastasis}

The role of exosome-induced breast cancer metastasis in promoting cancer progression is important. Cancer stem cells play an important role in the recurrence of breast cancer cell metastasis. Evidence suggests that exosomes derived from cancer stem cells have high levels of miR-155 that mediate the loss of CCAAT/enhancer-binding protein (C/EBP)- $\beta$, resulting in the loss of TGF- $\beta$, inducing cells to obtain an EMT phenotype (83). Furthermore, exosomal miR-155 has also been revealed to inhibit SOCS6, activate STAT3, and promote metastasis of breast cancer cells (75).

Transfer of exosomes between cancer cells promotes cancer metastasis. miR-24, miR-26a, and miR-27a in exosomes of docetaxel-resistant breast cancer cells are involved in cancer invasion and metastasis by activating the MAPK signaling pathway (19). Breast cancer cell exosomal miR-200c and miR-141 have also been demonstrated to promote breast cancer cell metastasis via a FOXP3-KAT2B-miR200c/141 axis (55). Exosomal miR-1246 secreted by MBCs was revealed to be transported to non-metastatic and non-malignant breast cancer cells, thereby inhibiting their target gene cyclin-g2 and resulting in enhanced breast cancer cell survival rates and mobility (49). Breast cancer cells have been revealed to deliver through exosomes, miR-10b to normal cells in which expression of miR-10b was lower than that of MDA-MB-231 cells. In non-malignant breast cancer cell line HMLE, miR-10b which has been revealed to promote migration of normal cells, targeted HOXD10 and Kruppel like factor 4 (KLF4) $(35,56)$. In addition to miRNAs, other molecules derived from cancer cells can also promote metastasis of cancer cells. Exosomal lncRNA UCA1 may enhance breast cancer cell activity, invasion and metastasis (40) through AKT-mTOR signaling (77). Maji et al revealed that breast cancer cell-derived exosomal Annexin A2 was responsible for brain and lung metastasis through activation of p38 MAPK mediated by macrophages, STAT3 and nuclear factor (NF)-kB, thereby improving levels of interleukin (IL)-6 and tumor necrosis factor (TNF)- $\alpha$ (84). In addition, Annexins A5 and A6 in breast cancer-derived exosomes may also be involved in cancer invasion and metastasis $(37,64,67,72,73)$.

The effect of breast cancer-derived exosomes on the microenvironment can also alter cancer metastasis. Exosomal Wnt 5a mRNA in MCF-7 was revealed to promote tumor invasion by activation of $\beta$-catenin-independent Wnt signaling in macrophages, where it could be translated to Wnt 5a protein (85). In addition, brain metastatic cancer cell-derived miR-181c in exosomes was demonstrated to target 3-phosphoinositide-dependent protein kinase-1 in endothelial cells, which disrupted the blood-brain barrier and caused breast cancer cells to metastasize to the brain (60). Similarly, exosomal miR-939 was demonstrated to directly target VE-cadherin, destroy the vascular endothelial barrier, and finally promote breast cancer cell migration (59). Exosomal miR-21 was also revealed to activate $\mathrm{NF}-\kappa \mathrm{B}$ and enhance invasion of stromal cells in breast phyllodes tumors (79).

Similar to proliferation, exosomes from the microenvironment can in turn affect cancer migration. RN7SL1 mRNA in exosomes of breast tumor fibroblasts could promote tumor metastasis through the NOTCH-MYC signaling pathway (86). It was reported that exosomal miR-223, released from tumor-associated macrophages that are activated by IL- 4 derived from $\mathrm{CD}^{+} \mathrm{T}$ cells could promote metastasis of breast cancer cells through the Mef $2 \mathrm{c} / \beta$-catenin pathway (62). miR-19a could be transported from astrocytes to breast cancer cells by exosomes, resulting in PTEN loss and promotion of brain metastasis of breast cancer cells (51). Doxorubicin was demonstrated to induce the expression of exosomal miR-126a in MDSCs, leading to breast cancer lung metastasis via an IL-33/IL-13-mediated pathway by which the miR-126a-S100A8/9 axis was regulated (18). Moreover, cancer-associated fibroblast (CAF)-derived exosomal miR-21, miR-143, and miR-378e have been reported to induce EMT phenotype and promote cell aggressiveness and metastasis by increasing organic cation transporter octamer-binding transcription factor 3/4 (Oct3/4), Nanog, and Sox2 expression in breast cancer cells (87). CAF-like (i.e., p $85 \alpha^{-/}$) fibroblast-derived exosomes were also revealed to deliver Wnt10b protein via the Wnt pathway, which resulted in enhanced migration, and EMT of breast cancer cells (74).

As aforementioned, there are numerous molecules that promote cancer migration. However, there are also some anticancer molecules from exosomes that can negatively regulate cancer migration. For example, miR-130a-3p was demonstrated to be downregulated in exosomes of breast 
cancer stem cell-like cells, and this inhibited cell invasion and metastasis by directly targeting RAB5B (30). Breast cancer cell exosomes carrying miR-134 were also revealed to act on the target proteins of receptor cells such as Bcl-2, STAT5B and heat shock protein 90 (Hsp90) to reduce tumor cell migration, invasion (54).

\section{Tumor angiogenesis}

Exosomes promote endothelial cell proliferation and increase angiogenesis by transferring cancer-promoting molecules. Hypoxic breast cancer cells have been revealed to transmit miR-210, which has been demonstrated to inhibit Ephrin-A3 and protein-tyrosine phosphatase 1B (PTP1B) via exosomes, and promote angiogenesis of breast cancer (88). When exosomes derived from MDA-MB-231 were co-cultured with HUVECs in vitro, they promoted proliferation and DNA synthesis of HUVECs in a time- and dose-dependent manner through activation of the MAPK pathway, resulting in changes in the vascular endothelial cell cycle and promotion of neovascularization (26). Doxorubicin-induced exosomal miR-126a released from MDSCs was demonstrated to contribute to induction of Th2 T cells and angiogenesis in breast cancer (18).

Similarly, some exosomal molecules can inhibit angiogenesis and play an anticancer role to some extent. Exosomal transport of miR-23b and miR-320b from breast cancer cells treated with docosahexaenoic acid reduced the expression of PLAU, AMOTL1, NRP1 and ETS2 genes in the recipient cells and inhibited angiogenesis in breast cancer (25). In addition, miR-16 in exosomes of MSCs contributed to the anti-angiogenic mechanism that directly regulates vascular endothelial growth factor (VEGF) expression (89). Bone marrow MSC-derived exosomes could also negatively regulate VEGF in breast cancer cells by transporting miR-100, and the mTOR/hypoxia-inducible factor (HIF)-1 $\alpha$ signaling axis was revealed to be involved in regulation, leading to the reduction of angiogenesis (90).

\section{Tumor thrombosis}

Breast cancer cell-derived exosomes have been reported to induce tissue factor (TF)-independent platelet activation and aggregation, as well as TF-dependent plasma coagulation and platelet activation and aggregation by producing thrombin and increasing vessel thrombosis (89). By targeting IL6 receptor, breast cancer cell-derived exosomal miR-21 was demonstrated to inhibit the action of endothelial progenitor cells that can be used for thrombectomy and reduce deep vein thrombosis, thereby facilitating thrombosis (28).

\section{Tumor autophagy}

Exosomes derived from breast cancer cell lines were revealed to induce autophagy at the phosphorylation site of the 15 th serine residue of p53 in normal human primary mammary epithelial cells. Autophagic proteins LC3 I and II were clearly detected in lysates of human mammary epithelial cells (HMECs) incubated with exosomes from MDA-MB-231 cells for up to $24 \mathrm{~h}$ (76).

\section{Tumor immune reaction}

Immune killing of tumor cells cannot be ignored. When the immune function is low or the tumor cells have the ability to escape from immune surveillance, tumors arise quietly. Exosomes derived from breast cancer can inhibit the activity of $\mathrm{T}$ cells by stimulating the proliferation of MDSCs and enhancing the immunosuppressive function, leading to immune evasion (29). Exosomes derived from breast cancer cell lines (MDA-MB-231 and MCF7) have been revealed to also be involved in the immunoregulation of macrophages. After contacting macrophages, the exosomes were revealed to bind to the surface of the macrophage Toll-like receptor 2 (TLR2) through its palmitoylated protein, which activates MyD88 in macrophages. The NF- $\mathrm{B}$ signaling pathway has been revealed to release a large number of inflammatory cytokines including granulocyte colony-stimulating factor (GC-SF), IL-6, CCL2/monocyte chemoattractant protein 1 (MCP1) and $\mathrm{TNF} \alpha$, and immunoregulate macrophages (29). This immune response was demonstrated to eventually enhance the rate of development of metastatic tumors. Exosomal proteins including calreticulin (CALR) (64), MHC class I molecules (31,65-67), and proteasome activator complex subunit 2 (PSME2) (64) have been reported to be involved in immune evasion of breast cancer. However, dendritic cell-derived exosomes were revealed to activate innate and acquired immune responses, which produce specific anti-breast cancer immune effects (26).

\section{Tumor treatment resistance}

Drug therapy of cancer is an important part of the anticancer process. The prognosis of patients is determined to some extent by drug resistance in the course of cancer treatment. It has been revealed that exosomes derived from cancer stem cells and chemoresistant breast cancer cells have higher levels of miR-155 by targeting forkhead box O3a (FOXO3a), and the drug resistance can be transmitted by exosomes to sensitive breast cancer cells (83).

Exosomal miR-451 released from breast cancer cells was revealed to bind to multidrug resistance 1 (MDR1) and reduce the expression of $\mathrm{P}$-glycoprotein $(\mathrm{P}-\mathrm{gp})$, resulting in cell resistance to doxorubicin, along with poor therapeutic efficacy (91). The expression levels of miR-17, miR-30a, miR-100 and miR-222 in exosomes were also increased and mediated drug resistance after treatment of paclitaxel or doxorubicin in MCF-7 cells (92). In addition, upregulated exosomal miR-1246 in breast cancer cells may lead to enhanced drug resistance and anti-chemotherapy activity by targeting CCNG2 (49). Moreover, docetaxel-resistant exosomal miRNAs such as miR-24(38,39,41), miR-23a (39), miR-222 (38), and miR-452 (42) were revealed to be capable of targeting p27, Sprouty2, PTEN, and anaphase promoting complex 4 (APC4) mRNAs respectively in target cells, conferring resistance to docetaxel-sensitive cells. Exosomal miR-4443 has also been revealed to lead to cell drug resistance (43). Similarly, miR-29-enriched exosomes have been revealed to be delivered to recipient breast cancer cells to promote resistance to doxorubicin by targeting PTEN (44). Except for the aforementioned molecules, tamoxifen-resistant LCC2-derived exosomes have been revealed to have high levels of lncRNA UCA1, rendering parental MCF-7 cells resistant 
to tamoxifen (45). In exosomes of SKBR-3/Tr and BT474/Tr breast cancer cells resistant to trastuzumab, the expression level of lncRNA-SNHG14 was significantly higher than that of the parental cells via the Bcl-2/Bax pathway (63). It has been revealed that transient receptor potential channel 5 (TrpC5) in exosomes of breast cancer may confer drug resistance to breast cancer cells (68) mediated by transcription factor nuclear factor of activated T-cell isoform c3 (NFATc3) $(93,94)$. It has been reported that ATP binding cassette subfamily $\mathrm{G}$ member 2 (ABCG2), a novel multidrug efflux transporter in exosomes in breast cancer, was associated with resistance to mitoxantrone and camptothecin analogs (69). Glutathione S-transferase P1 (GSTP1)-rich exosomes were able to confer drug resistance and were revealed to be useful in predicting chemoresistance (70). In addition, exosomes carrying ubiquitin carboxy-terminal hydrolase (UCH)-L1 and P-gp from doxorubicin-resistant human breast cancer cells (MCF7/ADM) could be integrated into cells sensitive to doxorubicin (MCF7/WT) to transfer chemoresistance (71).

Microenvironment-derived exosomes can also transmit drug resistance information to cancer cells. CAF-derived exosomal mitochondrial DNA (mtDNA) from hormonal therapy-naive breast cancer cells in patients promoted the development of hormonal therapy-resistant disease (95). Exosomal RNA RN7SL1 in breast tumor fibroblasts may lead to resistance to therapy in breast cancer cells (86). Exosomal miR-155 from tumor-associated macrophages (TAMs) was secreted into exosomes and transported to cancer cells. There, it targeted telomeric repeat-binding factor 1 , causing cancer cells to resist cisplatin (96).

\section{Differentiation and dedifferentiation of cells in the microenvironment}

MDA-MB-231 human breast cancer cells overexpressing exosomal miR-940 can promote osteogenic differentiation of host mesenchymal cells to induce extensive osteoblastic lesions in the final tumor (17). Breast cancer-derived exosomes were revealed to induce the differentiation of MSCs into fibroblasts by activating the signaling pathway mediated by TGF- $\beta$ receptor (97). They can also transform adipose tissue-derived MSCs into myofibroblast-like cells by activating the SMAD2-mediated intracellular signaling pathway (97). Concurrently, activation of SMAD2 was revealed to cause upregulation of fibroblast-related functional factors including stromal cell-derived factor 1 (SDF1), VEGF1, CCL5 and TGF- $\beta$, thereby increasing the expression of $\alpha$-smooth muscle actin ( $\alpha$-SMA) and presenting a phenotype of tumor-related fibroblasts (97). Conversely, exosomal miR-21, miR-143, and miR-378e in CAFs induced cell dedifferentiation to a stem-like state, through increased Oct $3 / 4$, Nanog, and Sox 2 expression in breast cancer cells (87).

\section{Exosomes as biomarkers in breast cancer}

Exosomal content used as biomarkers has several characteristics: i) Exogenous substances are stable and not degraded by external enzymes, thereby inferring that the integrity and function of the substance are unchanged (98); ii) exosomal substances can easily to be obtained in a noninvasive way in a wide range of body fluids, such as blood, urine, and saliva; iii) the number of proteins and RNAs in exosomes is higher than other types of extracellular vesicles and the content in exosomes is higher than in serum in several tumors, this indicates exosomal content may be rich in exosomes which could improve the detection sensitivity (99); iv) exosomal proteins and RNAs are cell-specific which may reflect the pathological state of different diseases (100). Therefore, exosomal contents are valuable markers for early diagnosis, prediction of prognosis, and evaluation of therapy in breast cancer (101).

Complete mtDNA was found in circulating exosomes of hormone-resistant breast cancer and may predict poor prognosis (102). CXC receptor 4 was revealed to be a highly expressed mRNA in the plasma exosomes of breast cancer and an indicator of poor prognosis (23). Breast cancer serum exosomal RN7SL1 RNA was revealed to be significantly associated with invasive breast cancer and may be a prognosis biomarker (20). Increased expression of exogenous exosomal hTERT mRNA, which reflects tumor burden and clinical status of patients in serum may indicate early diagnosis and recurrence of breast cancer (21).

microRNAs have been best described in studies that have analyzed the presence of genetic materials in exosomes. Combination of serum exosomal miR-21 and miR-1246 may be used as markers for early diagnosis $(103,104)$. Exosomal miR-301 and miR-155 are considered to be early predictors of breast cancer (105-107). Serum exosomal miR-101, miR-372 and miR-373 can be used as early diagnostic markers of breast cancer (3). Increased expression of exosomal miR-126a has been found in the serum of breast cancer patients resistant to doxorubicin therapy, which could be used as a predictor of chemosensitivity, diagnosis and prognosis of breast cancer (18). Serum exosomal miR-130a-3p of breast cancer may be used as a biomarker for the diagnosis and prognosis of breast cancer (30). Breast cancer exosomal miR-200c and miR-141 in plasma may be used as early predictors of cancer metastasis (55). Log-rank test analysis has revealed that the level of exosomal miR-378 was inversely correlated with the overall survival rate and was associated with adverse prognosis (75). In a study by Mihelich et al, an ideal candidate biomarker, miR-182, that contributed to disease aggressiveness was detected in the serum exosomes from breast cancer patients. It may be a biomarker of disease prognosis (108). Sueta et al assessed the level of serum exosomal RNA in breast cancer patients. The results revealed that miR-338-3p, miR124-3p, and miR-340-5p were upregulated rapidly and miR-29b-3p, miR-130a-3p, miR-20b-5p, miR-18a-5p, miR-486-5p, miR-17-5p, miR-195-5p, and miR-93-5p were downregulated in patients with breast cancer relapse (109). These results suggest that these genes are associated with breast cancer recurrence and can be used as prognostic indicators (109).

Breast cancer is a dynamic disease, and good diagnostic indicators can identify the type of disease and treat it in a timely manner. Especially for patients who have no metastasis, appropriate interventions, such as neoadjuvant therapy is required to prevent development of MBC. To evaluate the prognosis of breast cancer, researchers have compared the expression of miRNAs in serum exosomes at different stages of breast cancer. Expression of miR-21 and miR-105 in MBC was revealed to be significantly higher than those in healthy individuals (110). 
However, in comparison of expression in localized breast cancer (LBC) and MBC, only miR-21 expression was statistically significant (110). Serum exosomal miR-105 can be used as a potential marker to distinguish healthy individuals from patients with LBC (110). Therefore, with false-negative results that occur during the treatment, combination of miR-21 and miR-105 may help improve diagnosis (110). Zhou et al (22) found high expression of exosomal miR-105 in the serum of breast cancer patients with pre-metastasis, ongoing metastasis or distant metastasis. This indicates that miR-105 may predict early metastasis and be used as a prognostic indicator (22). The level of exosomal miR-143 was revealed to be higher in patients with high grade (III/IV) breast cancer, and it could be used as an indicator of breast cancer grading (87).

Breast cancer can be divided into the following molecular types: Luminal A, luminal B, HER2-positive and triple-negative. miR-100 has been revealed to be downregulated in various molecular subtypes of breast cancer, and it may be used as a marker for diagnosis and prognosis (27). Expression of serum exosomal miR-222 in luminal type A breast cancer was revealed to be significantly lower than in luminal type B and triple-negative breast cancer (TNBC) (110). Serum exosomal miR-27a was increased in patients with HER2-positive breast cancer, and serum miR-27b in exosomes was increased in HER2-positive and TNBC (111). The level of exosomal miR-373 was higher in patients with TNBC than other subtypes of breast cancer, and it has been revealed as a biological indicator of aggressive, hormone receptor-negative breast cancer $(112,113)$. Exosomal miR-939 was demonstrated to play an important role in metastasis via the blood or lymph node and was inversely related to prognosis in TNBC (59). These indicators are important to differentiate between numerous subtypes of breast cancer and targeted treatment should be implemented to prevent recurrence and resistance to therapy (110).

Exosomal miRNAs can also be used for monitoring therapy efficacy. As previously demonstrated after neoadjuvant chemotherapy (4 weeks after doxorubicin treatment), the tumor diameter in patients with LBC was decreased, expression of serum exosomal miR-21 was downregulated, and the expression level of miR-221 was decreased in patients with lymph node infection. These indicators can thus be used as prognostic indicators for doxorubicin treatment (110). It has also been demonstrated that the levels of serum exosomal miR-376a, miR-27a, miR-155, and miR-376c in breast cancer patients are dynamic, and reflect the cancer status and return to normal after adjuvant therapy (114). It was revealed that breast cancer patients treated with neoadjuvant therapy had increased expression of exosomal miR-503 (52), which may be used as an indicator of treatment efficacy (3). Therefore, dynamic measurement of miRNA levels in exosomes can reduce the rate of misdiagnosis and can also monitor treatment response and effect in real time.

Except for miRNAs, exosomes are acknowledged to contain several other ncRNAs, such as lncRNAs, which are also markers for breast cancer. IncRNA GAS5 in breast cancer cell exosomes, an inhibitor of cell proliferation and apoptosis promoter, could be used to evaluate the efficacy of chemotherapy and radiotherapy and be a biomarker of apoptosis induction (115). Exosomal lncRNA-SNHG14 was revealed to be increased in serum of HER2-positive breast cancer with resistance to trastuzumab, and it may be used as a diagnostic marker for breast cancer. The receiver operating characteristic (ROC) curve, which is used to evaluate diagnostic value, revealed an area under the curve (AUC) of 0.774 , along with a diagnostic sensitivity and specificity of 80.0 and $72.5 \%$ with the established cut-offs (3.09), respectively (63).

Several exosomal proteins are expressed in different stages or types of breast cancer and can be used as markers for general cancer diagnosis and prognosis. Moon et al $(116,117)$ revealed that the development of developmentally regulated endothelial locus 1 (Del-1) and fibronectin derived from circulating exosomes in plasma from breast cancer patients may be used as promising biomarkers in the early stage of the disease. Del-1 was also revealed as a potential marker for distinguishing breast cancer from benign breast tumors and other diseases. Ning et al (71) have demonstrated that exosomes containing UCH-L1 can transfer chemoresistance to recipient cells, and these exosomes can be used as non-invasive diagnostic biomarkers for detecting chemoresistance in patients with breast cancer. Exosomes containing amphiregulin (AREG) which binds to cell surface epidermal growth factor receptor (EGFR), were revealed to increase receptor breast cancer invasive ability of cells (118). Therefore, exosomes containing AREG may be used as prognostic and/or predictive markers (26). In a prior study it was revealed that compared with controls without disease for 5 years, patients with breast cancer had higher levels of survivin and its splice variants in serum. The results indicated that exosomal survivin-2B may be used as a diagnostic and/or prognostic indicator for early breast cancer patients (119). In a recent study, glypican 1 (GPC1) was identified as a novel cancer biomarker. It was revealed that, compared with healthy controls, $75 \%$ of breast cancer patients had high expression of $\mathrm{GPC}^{+}$circulating exosomes (120). In addition to tetraspanin CD9, HSP70, epithelial cell adhesion molecule (EpCAM) (121) and Annexin-1 (122), the metalloproteinase ADAM10 $(121,124)$ was also revealed to be uniquely expressed in breast cancer of serum or pleural effusion-derived exosomes from patients (123). Potential biomarkers of breast cancer are summarized in Table II.

\section{Exosomes in breast cancer therapy}

Via the secretion of exosomes, breast cancer cells affect the whole systemic environment to regulate the onset and development of cancer $(124,125)$. Therefore, it is a superior approach for cancer therapy to prevent exosomal formation and secretion $(124,125)$. In breast cancer, psoralen may reduce exosomal formation and secretion, thereby leading to MDR reversal (14). A novel strategy for treating cancer is the removal of HER2-positive exosomes from the whole circulatory system by application of affinity plasma exchange, established by the biotechnology company Aethlon Medical, Inc. This new strategy is helpful to inhibit the progression of HER2-positive breast cancer (126).

The important roles of exosomes in breast cancer suggest that they can be exploited as a therapeutic target. Increased mRNA expression levels of CD9, CD63, CD81 and tumor susceptibility gene 101 (TSG101) were revealed in breast cancer stem cell exosomes, which may serve as 
Table II. Potential application of exosomes in breast cancer.

\begin{tabular}{|c|c|c|c|c|}
\hline Cargo type & Exosomal cargo & Biofluids & Clinical value in GC & (Refs.) \\
\hline \multirow{6}{*}{$\begin{array}{l}\text { DNA } \\
\text { mRNA }\end{array}$} & Mitochondrial DNA & Serum & Indicator of poor prognosis & $(102)$ \\
\hline & CXCR4 & Plasma & Indicator of poor prognosis & (19) \\
\hline & RN7SL1 & Serum & $\begin{array}{l}\text { Associated with invasive breast cancer and } \\
\text { may be a prognosis biomarker }\end{array}$ & $(81)$ \\
\hline & hTERT & Serum & $\begin{array}{l}\text { Early diagnosis and recurrence of } \\
\text { breast cancer }\end{array}$ & $(21)$ \\
\hline & $\begin{array}{l}\text { mRNA expression } \\
\text { levels of CD9, CD63, } \\
\text { CD81 and TSG101 }\end{array}$ & $\begin{array}{l}\text { Breast cancer } \\
\text { stem cell }\end{array}$ & $\begin{array}{l}\text { Therapeutic targets for cancer treatment } \\
\text { and prevention }\end{array}$ & (127) \\
\hline & $\mathrm{CCNG} 2$ & Serum & Therapeutic targets for breast cancer & $(40)$ \\
\hline \multirow[t]{30}{*}{ miRNA } & miR-21 and miR-1246 & Serum & Markers for early diagnosis & $(103,104)$ \\
\hline & miR-301 and miR-155 & Serum & Early predictors of breast cancer & $(105-107)$ \\
\hline & $\begin{array}{l}\operatorname{miR}-101, \mathrm{miR}-372 \\
\text { and miR-373 }\end{array}$ & Serum & Early diagnostic markers of breast cancer & (3) \\
\hline & miR-126a & Serum & $\begin{array}{l}\text { A predictor of chemosensitivity, diagnosis } \\
\text { and prognosis of breast cancer }\end{array}$ & (30) \\
\hline & miR-130a-3p & Serum & A biomarker for diagnosis and prognosis & $(90)$ \\
\hline & miR-200c and miR-141 & Plasma & Early predictors of cancer metastasis & $(56)$ \\
\hline & miR-378 & Serum & $\begin{array}{l}\text { Inversely correlated with overall survival } \\
\text { rate and associated with adverse prognosis }\end{array}$ & $(37)$ \\
\hline & miR-182 & Serum & A biomarker of disease prognosis & $(108)$ \\
\hline & $\operatorname{miR}-338-3 p$ & Serum & Upregulated in relapsed patients & $(109)$ \\
\hline & $\operatorname{miR} 124-3 p$ & & Associated with breast cancer recurrence & \\
\hline & $\operatorname{miR}-340-5 p$ & & Prognostic indicators of breast cancer & \\
\hline & miR-29b-3p & Serum & Downregulated in relapsed patients & $(109)$ \\
\hline & $\operatorname{miR}-130 a-3 p$ & & Associated with breast cancer recurrence & \\
\hline & miR-20b-5p & & Prognostic indicators of breast cancer & \\
\hline & $\operatorname{miR}-18 a-5 p$ & & & \\
\hline & $\operatorname{miR}-486-5 p$ & & & \\
\hline & $\operatorname{miR} 17-5 p$ & & & \\
\hline & miR-195-5p & & & \\
\hline & miR-93-5p & & & \\
\hline & miR-21 and miR-105 & Serum & Differentiates MBC from healthy individuals & $(110)$ \\
\hline & $\operatorname{miR}-21$ & Serum & $\begin{array}{l}\text { Differentiates LBC from MBC } \\
\text { A prognostic indicator for doxorubicin } \\
\text { treatment }\end{array}$ & $(110)$ \\
\hline & $\operatorname{miR}-105$ & Serum & $\begin{array}{l}\text { Differentiates healthy people from LBC } \\
\text { A predictor of early metastasis } \\
\text { A prognostic indicator }\end{array}$ & $(61)$ \\
\hline & miR-143 & Serum & An indicator of breast cancer grading & (24) \\
\hline & $\operatorname{miR}-100$ & Serum & $\begin{array}{l}\text { Downregulated in various subtypes of breast } \\
\text { cancer and used as a marker for the diagnosis } \\
\text { and prognosis of breast cancer }\end{array}$ & $(27)$ \\
\hline & $\operatorname{miR}-222$ & Serum & Higher in luminal A tumors & $(110)$ \\
\hline & miR-27 & Serum & Higher in HER2-positive tumors & $(111)$ \\
\hline & $\operatorname{miR}-373$ & Serum & Higher in triple-negative breast cancer & $(112,113)$ \\
\hline & $\operatorname{miR}-939$ & Serum & Inversely related to prognosis in TNBCs & $(60)$ \\
\hline & miR-21, miR-221 & serum & $\begin{array}{l}\text { A prognostic indicator for doxorubicin } \\
\text { treatment }\end{array}$ & $(110)$ \\
\hline & $\begin{array}{l}\text { miR-376a } \\
\text { miR-27a } \\
\text { miR-155 } \\
\text { miR-376c }\end{array}$ & Serum & $\begin{array}{l}\text { Reflect the cancer status in real time and } \\
\text { return to normal levels after adjuvant } \\
\text { therapy }\end{array}$ & (114) \\
\hline
\end{tabular}


Table II. Continued.

\begin{tabular}{|c|c|c|c|c|}
\hline Cargo type & Exosomal cargo & Biofluids & Clinical value in GC & (Refs.) \\
\hline & miR-503 & Serum & An indicator of treatment monitoring & $(3,47)$ \\
\hline & $\operatorname{miR}-1246$ & Serum & Therapeutic targets for breast cancer & $(40,128)$ \\
\hline & miR-660 & & & \\
\hline \multirow[t]{7}{*}{ lncRNA } & GAS5 & MCF-7/ & Evaluate the efficacy of chemotherapy & $(115)$ \\
\hline & & MDA-MB-231 & and radiotherapy & \\
\hline & & cell culture & A marker of apoptosis induction & \\
\hline & & supernatants & & \\
\hline & SNHG14 & Serum & A diagnostic marker for breast cancer & $(138)$ \\
\hline & & & A therapeutic target for breast cancer & \\
\hline & MALAT1 & Serum & Therapeutic targets for breast cancer & $(129)$ \\
\hline \multirow[t]{8}{*}{ protein } & Del-1 & Plasma & $\begin{array}{l}\text { A promising biomarker in the early stage of } \\
\text { the disease and a potential marker for } \\
\text { distinguishing breast cancer from benign } \\
\text { breast tumors and other diseases }\end{array}$ & $(116,117)$ \\
\hline & Fibronectin & Plasma & $\begin{array}{l}\text { A promising biomarker in the early-stage } \\
\text { of the disease }\end{array}$ & $(116,117)$ \\
\hline & UCH-L1 & Serum & $\begin{array}{l}\text { A diagnostic biomarker for detecting } \\
\text { chemical resistance }\end{array}$ & $(96)$ \\
\hline & AREG & Serum & A prognostic and/or predictive marker. & $(89,118)$ \\
\hline & Survivin-2B & Serum & $\begin{array}{l}\text { A diagnostic and/or prognostic indicator } \\
\text { for early breast cancer }\end{array}$ & $(119)$ \\
\hline & GPC1 & Serum & A novel cancer biomarker & $(120)$ \\
\hline & CD9, HSP70, EpCAM & Serum/Pleural & Uniquely expressed in breast cancer & $(118)$ \\
\hline & Annexin-1, ADAM10 & effusion & & $(121-123)$ \\
\hline
\end{tabular}

useful biomarkers to provide new strategies for cancer treatment and prevention (127). Exosomal CCNG2 mRNA and miR-1246 could be used as therapeutic targets for breast cancer by inducing cell proliferation, migration, invasion, metastasis and drug resistance (49). miR-660 in serum exosomes is considered to regulate breast cancer cell proliferation, migration, and invasion, thereby serving as a therapeutic target for breast cancer (128). 1ncRNA MALAT1 was also revealed to be highly expressed in breast cancer cell exosomes and promoted cell proliferation, and thus may be used as a target gene for breast cancer treatment (129). Exosomal lncRNA-SNHG14 could be used as a therapeutic target for HER2-positive breast cancer with resistance to trastuzumab which was revealed to lead to distant metastasis (63).

Exosomes derived from stem cells are an efficient mode of drug delivery. The advantages are as follows: i) Stem cells can produce more exosomes (130); ii) exosomes derived from stem cells have improved ability for expansion in vivo (130); iii) stem cells harness strong differentiation ability (130); and iv) stem cells are free from activating the immune system, which renders stem cell exosomes a safe drug delivery tool (131).

Numerous strategies may be used to treat breast cancer by exosomes: Transfection of anti-RNA substances or anti-oncogenes into exosomes, drugs that interfere with loading or delivery of exosomal contents that promote tumors, or removal of specific exosomal compounds from circulation. Natural or synthetic exosomes in a specific cell type can utilize affinity to deliver activity-modulating compounds to other cancer cells or microenvironments to promote tumor suppressor contents or inhibit tumor promoter contents (3).

Exosomes derived from bone MSCs were demonstrated to effectively transport anti-miR-142-3p, thereby inhibiting the expression of miR-142-3p and miR-150 and increasing the level of APC mRNA and P2X purinoceptor 7 mRNA, thus leading to antitumor effects including decrease of cell viability, increase of apoptosis, significantly reduced tumor volume and weight, and extended survival (6). The let-7 miRNA from HCC70 cell-derived exosomes in human breast ductal carcinoma could inhibit EGFR-positive breast cancer in vivo (132). In addition, 293 cell-derived exosomes could deliver surface-modified with anti-EGFR peptides through cell engineering to inhibit the proliferation of breast cancer cells (133).

The microenvironment plays an important role in tumor development. Exosomes released from pre-adipocytes in the microenvironment of breast cancer can promote tumor invasion and metastasis (134). It has been reported that shikonin could inhibit tumor growth and increase the sensitivity of breast cancer cells to endocrine therapy (135). The differentiation of pre-adipocytes treated with shikonin was revealed to be reduced, and the content of miR-140 in the exosomes was increased, so that the SOX9/miR-140 signaling pathway in target cells was enhanced, thereby inhibiting the stem cell 
formation, tumor migration, and tumor growth of ductal carcinoma in situ (DCIS) in vivo (58). Therefore, drugs targeting the microenvironment are important for the prevention of invasive breast cancer.

Breast cancer cell exosomes carrying miR-134 were revealed to increase sensitivity to anticancer drugs (54). During breast cancer neoadjuvant chemotherapy, HUVECs were capable of transmitting miR-503 to breast tumor cells via exosomes, which was helpful to the antitumor response (52). Tumor-derived exosomes are composed of various cytosol membranous tumor antigens, molecules involved in antigen presentation, which may be promising candidates for cancer vaccines $(136,137)$.

\section{Exosomes and other diseases}

In addition to breast cancer, exosomes have been reported in several other tumors and benign diseases. Thus far, they have been recognized as potential biomarkers for cancer diagnostics due to their characteristics (139-142). Since exosomes can be secreted by all cells and circulate in the body fluids, specific detection and isolation of cancer cell-derived exosomes are urgently required to identify the different diseases. $\mathrm{GPC}^{+}$circulating exosomes were detected in the serum of patients with pancreatic ductal adenocarcinoma (PDCA) with absolute specificity and sensitivity (120). CLDN4, EPCAM as well as other exosome 'surfaceome' were revealed to be PDAC-specific biomarker candidates (143). Surface-enhanced Raman scattering technology for rapid and label-free exosomal detection (Exo-SERS) and multiplex proximity extension assays (PEA) are helpful in the identification of various exosomes from different sources $(144,145)$. Furthermore, due to the heterogeneity of exosomes, it is desirable to investigate them individually by using different techniques such as antibody-DNA conjugates and next-generation sequencing which combines a proximity-dependent barcoding assay or a sequential quantification analysis utilizing DNA-PAINT. In the future, profiling of multiple exosomal surface biomarkers at the single-exosome level may be detected to distinguish exosomes from different diseases $(146,147)$. An increasing number of specific exosomal molecules may be established for the identification of different diseases.

\section{Obstacles and future outlook}

Substances in the exosomes, such as DNAs, mRNAs, proteins, miRNAs and lncRNAs, play important roles in tumor cell communication and remodeling of the tumor microenvironment. The study of exosomes provides a new perspective for the diagnosis and prognosis of tumors. Furthermore, exosomes and their contents have become new targets for cancer treatment.

Although exosome research is promising, some issues affect research of exosomes. (1) In vivo, the potential effect of exosomes from cancer cells on recipient cells may rely on some environmental parameters and accessibility barriers (34). It is impossible to guarantee whether the exosomal content in the in vitro co-culture technique is within the physiological range (148). (2) All cells can release exosomes. Cancer cells or CAF-derived exosomes account for a small proportion, thus there are several research obstacles in finding markers to identify exosomes of cancer cell origin and increasing the number of exosomes in order to extract and detect abundant contents (149). (3) An endogenous control used to normalize the expression of exosomal contents is lacking. Without a reference content, different publications may report conflicting data on the level of exosomal contents. Furthermore, standardization of the approaches are important in order to obtain common concepts for exosome assays and reporting results, with international cooperation among the scientists (150). (4) When the patient has other diseases, the expression of exosomal contents is variable and not specific, thus the appropriate statistical tests should be used when analyzing the data (112). (5) As aforementioned, when exosomes are used to treat breast cancer, stem cell-derived exosomes can be excellent drug carriers, however, they also have several shortcomings. For example, their biodistribution and in vivo clearance functions have not been elucidated (151-154), which may have adverse side effects in humans, such as acute renal injury (155). In addition, stem cell-derived exosomes have some cytotoxicity and tumor tropism (6). Therefore, a method is required to control the particle size of exosomes, allowing them to fully function in the body, and be effectively removed in a timely manner (6). This will provide more constructive insights into the diagnosis and treatment of breast cancer exosomes after these issues are resolved (43).

\section{Acknowledgements}

Not applicable.

\section{Funding}

This study was supported by the National Natural Science Foundation of China (grant no. 81702078), the Natural Science Foundation of Jiangsu Province (grant no. BK20170356), the Natural Science Fund for Colleges and Universities of Jiangsu Province (grant no. 17KJB320016), the Suzhou Science and Technology Project (grant no. SYS201728), the Postgraduate Research and Practice Innovation Program of Jiangsu Province (grant no. KYCX18_2535), the Young Stuff Pre-research Fund Project of The Second Affiliated Hospital of Soochow University (grant no. SDFEYQN1718).

\section{Availability of data and materials}

$$
\text { Not applicable. }
$$

\section{Authors' contributions}

HY conceived the study. LW and BW collected the literature and wrote the review. HW, JM and YR prepared the tables and participated in the writing of the manuscript. All authors read, reviewed, and approved the final manuscript. LW and BW contributed equally to this work.

\section{Ethics approval and consent to participate}

Not applicable. 


\section{Patient consent for publication}

Not applicable.

\section{Competing interests}

The authors declare that they have no competing interests.

\section{References}

1. Ferlay J, Soerjomataram I, Dikshit R, Eser S, Mathers C, Rebelo M, Parkin DM, Forman D and Bray F: Cancer incidence and mortality worldwide: Sources, methods and major patterns in GLOBOCAN 2012. Int J Cancer 136: E359-E386, 2015.

2. Siegel RL, Miller KD and Jemal A: Cancer statistics, 2017. CA Cancer J Clin 67: 7-30, 2017

3. Sempere LF, Keto J and Fabbri M: Exosomal MicroRNAs in breast cancer towards diagnostic and therapeutic applications. Cancers (Basel) 9: pii: E71, 2017.

4. Bardelli A and Pantel K: Liquid biopsies, what we do not know (Yet). Cancer Cell 31: 172-179, 2017.

5. Kalra H, Drummen GP and Mathivanan S: Focus on extracellular vesicles: Introducing the next small big thing. Int J Mol Sci 17: 170, 2016.

6. Naseri Z, Oskuee RK, Jaafari MR and Forouzandeh Moghadam M: Exosome-mediated delivery of functionally active miRNA-142-3p inhibitor reduces tumorigenicity of breast cancer in vitro and in vivo. Int J Nanomedicine 13: 7727-7747, 2018.

7. Tkach M and Théry C: Communication by extracellular vesicles: Where we are and where we need to go. Cell 164: 1226-1232, 2016.

8. Zhang $\mathrm{X}$, Shi $\mathrm{H}$, Yuan $\mathrm{X}$, Jiang $\mathrm{P}$, Qian $\mathrm{H}$ and $\mathrm{Xu} \mathrm{W}$ : Tumor-derived exosomes induce N2 polarization of neutrophils to promote gastric cancer cell migration. Mol Cancer 17: 146, 2018.

9. Jin Y, Chen K, Wang Z, Wang Y, Liu J, Lin L, Shao Y, Gao L, Yin $\mathrm{H}$, Cui C, et al: DNA in serum extracellular vesicles is stable under different storage conditions. BMC Cancer 16: 753, 2016.

10. Li Q, Shao Y, Zhang X, Zheng T, Miao M, Qin L, Wang B, Ye G, Xiao B and Guo J: Plasma long noncoding RNA protected by exosomes as a potential stable biomarker for gastric cancer. Tumour Biol 36: 2007-2012, 2015.

11. Street JM, Koritzinsky EH, Glispie DM, Star RA and Yuen PS: Urine exosomes: An emerging trove of biomarkers. Adv Clin Chem 78: 103-122, 2017.

12. Nair S, Tang KD, Kenny L and Punyadeera C: Salivary exosomes as potential biomarkers in cancer. Oral Oncol 84: 31-40, 2018.

13. Yang H, Fu H, Xu W and Zhang X: Exosomal non-coding RNAs: A promising cancer biomarker. Clin Chem Lab Med 54: 1871-1879, 2016.

14. Wang X, Xu C, Hua Y, Sun L, Cheng K, Jia Z, Han Y, Dong J, Cui Y and Yang Z: Exosomes play an important role in the process of psoralen reverse multidrug resistance of breast cancer. J Exp Clin Cancer Res 35: 186, 2016.

15. Conte D, Verri C, Borzi C, Suatoni P, Pastorino U, Sozzi G and Fortunato O: Novel method to detect microRNAs using chip-based QuantStudio 3D digital PCR. BMC Genomics 16: 849, 2015.

16. Jeong S, Park J, Pathania D, Castro CM, Weissleder R and Lee H: Integrated magneto-electrochemical sensor for exosome analysis. ACS Nano 10: 1802-1809, 2016

17. Singh CK, Kumar A and Roy SS: Quantitative analysis of the methane gas emissions from municipal solid waste in India. Sci Rep 8: 2913, 2018.

18. Deng Z, Rong Y, Teng Y, Zhuang X, Samykutty A, Mu J, Zhang L, Cao P, Yan J, Miller D and Zhang HG: Exosomes miR-126a released from MDSC induced by DOX treatment promotes lung metastasis. Oncogene 36: 639-651, 2017.

19. Sebolt-Leopold JS and Herrera R: Targeting the mitogen-activated protein kinase cascade to treat cancer. Nat Rev Cancer 4 937-947, 2004

20. Zhou R, Chen KK, Zhang J, Xiao B, Huang Z, Ju C, Sun J, Zhang F, Lv XB and Huang G: The decade of exosomal long RNA species: An emerging cancer antagonist. Mol Cancer 17: 75,2018 .
21. Goldvaser H, Gutkin A, Beery E, Edel Y, Nordenberg J, Wolach O, Rabizadeh E, Uziel O and Lahav M: Characterisation of blood-derived exosomal hTERT mRNA secretion in cancer patients: A potential pan-cancer marker. Br J Cancer 117: 353-357, 2017.

22. Zhou W, Fong MY, Min Y, Somlo G, Liu L, Palomares MR, Yu Y, Chow A, O'Connor ST, Chin AR, et al: Cancer-secreted miR-105 destroys vascular endothelial barriers to promote metastasis. Cancer Cell 25: 501-515, 2014.

23. Rodriguez M, Silva J, Herrera A, Herrera M, Peña C, Martín P, Gil-Calderón B, Larriba MJ, Coronado MJ, Soldevilla B, et al: Exosomes enriched in stemness/metastatic-related mRNAS promote oncogenic potential in breast cancer. Oncotarget 6 : 40575-40587, 2015.

24. Yan LX, Wu QN, Zhang Y, Li YY, Liao DZ, Hou JH, Fu J, Zeng MS, Yun JP, Wu QL, et al: Knockdown of miR-21 in human breast cancer cell lines inhibits proliferation, in vitro migration and in vivo tumor growth. Breast Cancer Res 13: R2, 2011.

25. Hannafon BN, Carpenter KJ, Berry WL, Janknecht R, Dooley WC and Ding WQ: Exosome-mediated microRNA signaling from breast cancer cells is altered by the anti-angiogenesis agent docosahexaenoic acid (DHA). Mol Cancer 14: 133, 2015.

26. Bi TL, Sun JJ, Tian YZ and Zhou YF: Research progress of relationship between exosomes and breast cancer. Sheng Li Xue Bao 68: 352-358, 2016 (In Chinese).

27. Chen D, Sun Y, Yuan Y, Han Z, Zhang P, Zhang J, You MJ, Teruya-Feldstein J, Wang M, Gupta S, et al: miR-100 induces epithelial-mesenchymal transition but suppresses tumorigenesis, migration and invasion. PLoS Genet 10: e1004177, 2014

28. Wang W, Yuan X, Xu A, Zhu X, Zhan Y, Wang S and Liu M: Human cancer cells suppress behaviors of endothelial progenitor cells through miR-21 targeting IL6R. Microvasc Res 120: 21-28, 2018.

29. Chow A, Zhou W, Liu L, Fong MY, Champer J, Van Haute D, Chin AR, Ren X, Gugiu BG, Meng Z, et al: Macrophage immunomodulation by breast cancer-derived exosomes requires Toll-like receptor 2-mediated activation of NF-kB. Sci Rep 4: 5750, 2014.

30. Kong X, Zhang J, Li J, Shao J and Fang L: MiR-130a-3p inhibits migration and invasion by regulating RAB5B in human breast cancer stem cell-like cells. Biochem Biophys Res Commun 501: 486-493, 2018

31. Clayton A and Tabi Z: Exosomes and the MICA-NKG2D system in cancer. Blood Cells Mol Dis 34: 206-213, 2005.

32. Vallabhaneni KC, Penfornis P, Dhule S, Guillonneau F, Adams KV, Mo YY, Xu R, Liu Y, Watabe K, Vemuri MC and Pochampally R: Extracellular vesicles from bone marrow mesenchymal stem/stromal cells transport tumor regulatory microRNA, proteins, and metabolites. Oncotarget 6: 4953-4967, 2015.

33. Zhu S, Si ML, Wu H and Mo YY: MicroRNA-21 targets the tumor suppressor gene tropomyosin 1 (TPM1). J Biol Chem 282: 14328-14336, 2007.

34. Melo SA, Sugimoto H, O'Connell JT, Kato N, Villanueva A, Vidal A, Qiu L, Vitkin E, Perelman LT, Melo CA, et al: Cancer exosomes perform cell-independent microRNA biogenesis and promote tumorigenesis. Cancer Cell 26: 707-721, 2014.

35. Ma L, Teruya-Feldstein $\mathbf{J}$ and Weinberg RA: Tumour invasion and metastasis initiated by microRNA-10b in breast cancer. Nature 449: 682-688, 2007.

36. Ochieng J, Pratap S, Khatua AK and Sakwe AM: Anchorage-independent growth of breast carcinoma cells is mediated by serum exosomes. Exp Cell Res 315: 1875-1888, 2009.

37. Brandes AA, Franceschi E, Tosoni A, Hegi ME and Stupp R: Epidermal growth factor receptor inhibitors in neuro-oncology: Hopes and disappointments. Clin Cancer Res 14: 957-960, 2008.

38. Zhong S, Li W, Chen Z, Xu J and Zhao J: MiR-222 and miR-29a contribute to the drug-resistance of breast cancer cells. Gene 531: 8-14, 2013.

39. Li X, Liu X, Xu W, Zhou P, Gao P, Jiang S, Lobie PE and Zhu T: c-MYC-regulated miR-23a/24-2/27a cluster promotes mammary carcinoma cell invasion and hepatic metastasis by targeting Sprouty2. J Biol Chem 288: 18121-18133, 2013.

40. Li X, Wu Y, Liu A and Tang X: Long non-coding RNA UCA1 enhances tamoxifen resistance in breast cancer cells through a miR-18a-HIF1 $\alpha$ feedback regulatory loop. Tumour Biol 37: 14733-14743, 2016

41. Giglio S, Cirombella R, Amodeo R, Portaro L, Lavra L and Vecchione A: MicroRNA miR-24 promotes cell proliferation by targeting the CDKs inhibitors p27Kip1 and p16INK4a. J Cell Physiol 228: 2015-2023, 2013. 
42. Chen WX, Cai YQ, Lv MM, Chen L, Zhong SL, Ma TF, Zhao JH and Tang JH: Exosomes from docetaxel-resistant breast cancer cells alter chemosensitivity by delivering microRNAs. Tumour Biol 35: 9649-9659, 2014

43. He Y, Deng F, Yang S, Wang D, Chen X, Zhong S, Zhao J and Tang J: Exosomal microRNA: A novel biomarker for breast cancer. Biomark Med 12: 177-188, 2018.

44. Shen H, Li L, Yang S, Wang D, Zhong S, Zhao J and Tang J: MicroRNA-29a contributes to drug-resistance of breast cancer cells to adriamycin through PTEN/AKT/GSK3 $\beta$ signaling pathway. Gene 593: 84-90, 2016.

45. Xu CG, Yang MF, Ren YQ, Wu CH and Wang LQ: Exosomes mediated transfer of lncRNA UCA1 results in increased tamoxifen resistance in breast cancer cells. Eur Rev Med Pharmacol Sci 20: 4362-4368, 2016.

46. Matula Z, Németh A, Lőrincz P, Szepesi Á, Brózik A, Buzás EI, Lőw P, Német K, Uher F and Urbán VS: The role of extracellular vesicle and tunneling nanotube-mediated intercellular cross-talk between mesenchymal stem cells and human peripheral T cells. Stem Cells Dev 25: 1818-1832, 2016

47. Ono M, Kosaka N, Tominaga N, Yoshioka Y, Takeshita F, Takahashi RU, Yoshida M, Tsuda H, Tamura K and Ochiya T: Exosomes from bone marrow mesenchymal stem cells contain a microRNA that promotes dormancy in metastatic breast cancer cells. Sci Signal 7: ra63, 2014.

48. Wei Y, Li M, Cui S, Wang D, Zhang CY, Zen K and Li L: Shikonin inhibits the proliferation of human breast cancer cells by reducing tumor-derived exosomes. Molecules 21: pii: E777, 2016.

49. Gorczynski RM, Zhu F, Chen Z, Kos O and Khatri I: A comparison of serum miRNAs influencing metastatic growth of EMT6 vs 4THM tumor cells in wild-type and CD200R1KO mice. Breast Cancer Res Treat 162: 255-266, 2017.

50. Wei Y, Lai X, Yu S, Chen S, Ma Y, Zhang Y, Li H, Zhu X, Yao L and Zhang J: Exosomal miR-221/222 enhances tamoxifen resistance in recipient ER-positive breast cancer cells. Breast Cancer Res Treat 147: 423-431, 2014.

51. Zhang L, Zhang S, Yao J, Lowery FJ, Zhang Q, Huang WC, Li P, Li M, Wang X, Zhang C, et al: Microenvironment-induced PTEN loss by exosomal microRNA primes brain metastasis outgrowth Nature 527: 100-104, 2015.

52. Bovy N, Blomme B, Frères P, Dederen S, Nivelles O, Lion M Carnet O, Martial JA, Noël A, Thiry M, et al: Endothelial exosomes contribute to the antitumor response during breast cancer neoadjuvant chemotherapy via microRNA transfer. Oncotarget 6: 10253-10266, 2015.

53. Lim PK, Bliss SA, Patel SA, Taborga M, Dave MA, Gregory LA, Greco SJ, Bryan M, Patel PS and Rameshwar P: Gap junction-mediated import of microRNA from bone marrow stromal cells can elicit cell cycle quiescence in breast cancer cells. Cancer Res 71: 1550-1560, 2011.

54. O'Brien K, Lowry MC, Corcoran C, Martinez VG, Daly M, Rani S, Gallagher WM, Radomski MW, MacLeod RA and O'Driscoll L: miR-134 in extracellular vesicles reduces triple-negative breast cancer aggression and increases drug sensitivity. Oncotarget 6 : 32774-32789, 2015.

55. Zhang G, Zhang W, Li B, Stringer-Reasor E, Chu C, Sun L, Bae S, Chen D, Wei S, Jiao K, et al: MicroRNA-200c and microRNA141 are regulated by a FOXP3-KAT2B axis and associated with tumor metastasis in breast cancer. Breast Cancer Res 19: 73, 2017.

56. Singh R, Pochampally R, Watabe K, Lu Z and Mo YY: Exosome-mediated transfer of miR-10b promotes cell invasion in breast cancer. Mol Cancer 13: 256, 2014

57. Fong MY, Zhou W, Liu L, Alontaga AY, Chandra M, Ashby J, Chow A, O'ConnorST, LiS, Chin AR, et al: Breast-cancer-secreted miR-122 reprograms glucose metabolism in premetastatic niche to promote metastasis. Nat Cell Biol 17: 183-194, 2015.

58. Gernapudi R, Yao Y, Zhang Y, Wolfson B, Roy S, Duru N, Eades G, Yang P and Zhou Q: Targeting exosomes from preadipocytes inhibits preadipocyte to cancer stem cell signaling in early-stage breast cancer. Breast Cancer Res Treat 150: 685-695, 2015.

59. Di Modica M, Regondi V, Sandri M, Iorio MV, Zanetti A, Tagliabue E, Casalini P and Triulzi T: Breast cancer-secreted miR-939 downregulates VE-cadherin and destroys the barrier function of endothelial monolayers. Cancer Lett 384: 94-100, 2017.

60. Tominaga N, Kosaka N, Ono M, Katsuda T, Yoshioka Y, Tamura K, Lötvall J, Nakagama $H$ and Ochiya T: Brain metastatic cancer cells release microRNA-181c-containing extracellular vesicles capable of destructing blood-brain barrier. Nat Commun 6: 6716, 2015.
61. Baroni S, Romero-Cordoba S, Plantamura I, Dugo M, D'Ippolito E, Cataldo A, Cosentino G, Angeloni V, Rossini A, Daidone MG and Iorio MV: Exosome-mediated delivery of miR-9 induces cancer-associated fibroblast-like properties in human breast fibroblasts. Cell Death Dis 7: e2312, 2016.

62. Yang M, Chen J, Su F, Yu B, Su F, Lin L, Liu Y, Huang JD and Song E: Microvesicles secreted by macrophages shuttle invasion-potentiating microRNAs into breast cancer cells. Mol Cancer 10: 117, 2011.

63. Dong H, Wang W, Chen R, Zhang Y, Zou K, Ye M, He X, Zhang F and Han J: Exosome-mediated transfer of lncRNA-SNHG14 promotes trastuzumab chemoresistance in breast cancer. Int J Oncol 53: 1013-1026, 2018.

64. Klinke DJ II, Kulkarni YM, Wu Y and Byrne-Hoffman C: Inferring alterations in cell-to-cell communication in HER $2^{+}$ breast cancer using secretome profiling of three cell models. Biotechnol Bioeng 111: 1853-1863, 2014.

65. Zheng Y, Campbell EC, Lucocq J, Riches A and Powis SJ: Monitoring the Rab27 associated exosome pathway using nanoparticle tracking analysis. Exp Cell Res 319: 1706-1713, 2013.

66. Bard MP, Hegmans JP, Hemmes A, Luider TM, Willemsen R, Severijnen LA, van Meerbeeck JP, Burgers SA, Hoogsteden HC and Lambrecht BN: Proteomic analysis of exosomes isolated from human malignant pleural effusions. Am J Respir Cell Mol Biol 31: 114-121, 2004

67. Palazzolo G, Albanese NN, DI Cara G, Gygax D, Vittorelli ML and Pucci-Minafra I: Proteomic analysis of exosome-like vesicles derived from breast cancer cells. Anticancer Res 32: 847-860, 2012

68. Ma X, Chen Z, Hua D, He D, Wang L, Zhang P, Wang J, Cai Y, Gao C, Zhang X, et al: Essential role for TrpC5-containing extracellular vesicles in breast cancer with chemotherapeutic resistance. Proc Natl Acad Sci USA 111: 6389-6394, 2014

69. Kong JN, He Q, Wang G, Dasgupta S, Dinkins MB, Zhu G, Kim A, Spassieva S and Bieberich E: Guggulsterone and bexarotene induce secretion of exosome-associated breast cancer resistance protein and reduce doxorubicin resistance in MDA-MB-231 cells. Int J Cancer 137: 1610-1620, 2015.

70. Yang SJ, Wang DD, Li J, Xu HZ, Shen HY, Chen X, Zhou SY, Zhong SL, Zhao JH and Tang JH: Predictive role of GSTP1-containing exosomes in chemotherapy-resistant breast cancer. Gene 623: 5-14, 2017.

71. Ning K, Wang T, Sun X, Zhang P, Chen Y, Jin J and Hua D: UCH-L1-containing exosomes mediate chemotherapeutic resistance transfer in breast cancer. J Surg Oncol 115: 932-940, 2017.

72. Kesimer M, Scull M, Brighton B, DeMaria G, Burns K, O'Neal W, Pickles RJ and Sheehan JK: Characterization of exosome-like vesicles released from human tracheobronchial ciliated epithelium: A possible role in innate defense. FASEB J 23: 1858-1868, 2009.

73. Villarreal L, Méndez O, Salvans C, Gregori J, Baselga J and Villanueva J: Unconventional secretion is a major contributor of cancer cell line secretomes. Mol Cell Proteomics 12: 1046-1060, 2013.

74. Chen Y, Zeng C, Zhan Y, Wang H, Jiang X and Li W: Aberrant low expression of $\mathrm{p} 85 \alpha$ in stromal fibroblasts promotes breast cancer cell metastasis through exosome-mediated paracrine Wnt10b. Oncogene 36: 4692-4705, 2017.

75. Muluhngwi $\mathrm{P}$ and Klinge CM: Identification of miRNAs as biomarkers for acquired endocrine resistance in breast cancer. Mol Cell Endocrinol 456: 76-86, 2017.

76. Dutta S, Warshall C, Bandyopadhyay C, Dutta D and Chandran B: Interactions between exosomes from breast cancer cells and primary mammary epithelial cells leads to generation of reactive oxygen species which induce DNA damage response, stabilization of p53 and autophagy in epithelial cells. PLoS One 9: e97580, 2014.

77. Wu C and Luo J: Long non-coding RNA (lncRNA) urothelial carcinoma-associated 1 (UCA1) enhances tamoxifen resistance in breast cancer cells via inhibiting mTOR signaling pathway. Med Sci Monit 22: 3860-3867, 2016.

78. Gutkin A, Uziel O, Beery E, Nordenberg J, Pinchasi M, Goldvaser H, Henick S, Goldberg M and Lahav M: Tumor cells derived exosomes contain hTERT mRNA and transform nonmalignant fibroblasts into telomerase positive cells. Oncotarget 7 : 59173-59188, 2016.

79. Gong C, Nie Y, Qu S, Liao JY, Cui X, Yao H, Zeng Y, Su F, Song E and Liu Q: miR-21 induces myofibroblast differentiation and promotes the malignant progression of breast phyllodes tumors. Cancer Res 74: 4341-4352, 2014. 
80. Baglio SR, Rooijers K, Koppers-Lalic D, Verweij FJ, Pérez Lanzón M, Zini N, Naaijkens B, Perut F, Niessen HW, Baldini N and Pegtel DM: Human bone marrow- and adipose-mesenchymal stem cells secrete exosomes enriched in distinctive miRNA and tRNA species. Stem Cell Res Ther 6: 127, 2015.

81. Frankel LB, Christoffersen NR, Jacobsen A, Lindow M, Krogh A and Lund AH: Programmed cell death 4 (PDCD4) is an important functional target of the microRNA miR-21 in breast cancer cells. J Biol Chem 283: 1026-1033, 2008.

82. Si ML, Zhu S, Wu H, Lu Z, Wu F and Mo YY: miR-21-mediated tumor growth. Oncogene 26: 2799-2803, 2007.

83. Yu DD, Lv MM, Chen WX, Zhong SL, Zhang XH, Chen L, Ma TF, Tang JH and Zhao JH: Role of miR-155 in drug resistance of breast cancer. Tumour Biol 36: 1395-1401, 2015.

84. Maji S, Chaudhary P, Akopova I, Nguyen PM, Hare RJ Gryczynski I and Vishwanatha JK: Exosomal annexin II promotes angiogenesis and breast cancer metastasis. Mol Cancer Res 15: 93-105, 2017.

85. Menck K, Klemm F, Gross JC, Pukrop T, Wenzel D and Binder C: Induction and transport of Wnt 5a during macrophage-induced malignant invasion is mediated by two types of extracellular vesicles. Oncotarget 4: 2057-2066, 2013.

86. Nabet BY, Qiu Y, Shabason JE, Wu TJ, Yoon T, Kim BC, Benci JL, DeMichele AM, Tchou J, Marcotrigiano J and Minn AJ: Exosome RNA unshielding couples stromal activation to pattern recognition receptor signaling in cancer. Cell 170: 352-366.e13, 2017.

87. Donnarumma E, Fiore D, Nappa M, Roscigno G, Adamo A, Iaboni M, Russo V, Affinito A, Puoti I, Quintavalle C, et al: Cancer-associated fibroblasts release exosomal microRNAs that dictate an aggressive phenotype in breast cancer. Oncotarget 8: 19592-19608, 2017

88. Jung KO, Youn $\mathrm{H}$, Lee $\mathrm{CH}$, Kang $\mathrm{KW}$ and Chung JK: Visualization of exosome-mediated miR-210 transfer from hypoxic tumor cells. Oncotarget 8: 9899-9910, 2017.

89. Lee JK, Park SR, Jung BK, Jeon YK, Lee YS, Kim MK, Kim YG, Jang JY and Kim CW: Exosomes derived from mesenchymal stem cells suppress angiogenesis by down-regulating VEGF expression in breast cancer cells. PLoS One 8: e84256, 2013.

90.Pakravan K, Babashah S, Sadeghizadeh M, Mowla SJ, Mossahebi-Mohammadi M, Ataei F, Dana N and Javan M MicroRNA-100 shuttled by mesenchymal stem cell-derived exosomes suppresses in vitro angiogenesis through modulating the $\mathrm{mTOR} / \mathrm{HIF}-1 \alpha / \mathrm{VEGF}$ signaling axis in breast cancer cells Cell Oncol (Dordr) 40: 457-470, 2017.

91. Chen WX, Zhong SL, Ji MH, Pan M, Hu Q, Lv MM, Luo Z, Zhao JH and Tang JH: MicroRNAs delivered by extracellular vesicles: An emerging resistance mechanism for breast cancer. Tumour Biol 35: 2883-2892, 2014.

92. Chen WX, Liu XM, Lv MM, Chen L, Zhao JH, Zhong SL, Ji MH, Hu Q, Luo Z, Wu JZ and Tang JH: Exosomes from drug-resistant breast cancer cells transmit chemoresistance by a horizontal transfer of microRNAs. PLoS One 9: e95240, 2014.

93. Dong Y, Pan Q, Jiang L, Chen Z, Zhang F, Liu Y, Xing H, Shi M, Li J, Li X, et al: Tumor endothelial expression of $\mathrm{P}$-glycoprotein upon microvesicular transfer of TrpC5 derived from adriamycin-resistant breast cancer cells. Biochem Biophys Res Commun 446: 85-90, 2014

94. Ma X, Cai Y, He D, Zou C, Zhang P, Lo CY, Xu Z, Chan FL Yu S, Chen Y, et al: Transient receptor potential channel TRPC5 is essential for P-glycoprotein induction in drug-resistant cancer cells. Proc Natl Acad Sci USA 109: 16282-16287, 2012

95. Sansone P, Savini C, Kurelac I, Chang Q, Amato LB, Strillacci A, Stepanova A, Iommarini L, Mastroleo C, Daly L, et al: Packaging and transfer of mitochondrial DNA via exosomes regulate escape from dormancy in hormonal therapy-resistant breast cancer. Proc Natl Acad Sci USA 114: E9066-E9075, 2017.

96. Challagundla KB, Wise PM, Neviani P, Chava H, Murtadha M, $\mathrm{Xu} \mathrm{T}$, Kennedy $\mathrm{R}$, Ivan $\mathrm{C}$, Zhang $\mathrm{X}$, Vannini I, et al: Exosome-mediated transfer of microRNAs within the tumor microenvironment and neuroblastoma resistance to chemotherapy. J Natl Cancer Inst 107: pii: djv135, 2015.

97. Cho JA, Park H, Lim EH and Lee KW: Exosomes from breast cancer cells can convert adipose tissue-derived mesenchymal stem cells into myofibroblast-like cells. Int J Oncol 40: 130-138, 2012

98. Berrondo C, Flax J, Kucherov V, Siebert A, Osinski T, Rosenberg A, Fucile C, Richheimer S and Beckham CJ: Expression of the long non-coding RNA HOTAIR correlates with disease progression in bladder cancer and is contained in bladder cancer patient urinary exosomes. PLoS One 11: e0147236, 2016.
99. Dong L, Lin W, Qi P, Xu MD, Wu X, Ni S, Huang D, Weng WW, Tan C, Sheng W, et al: Circulating long RNAs in serum extracellular vesicles: Their characterization and potential application as biomarkers for diagnosis of colorectal cancer. Cancer Epidemiol Biomarkers Prev 25: 1158-1166, 2016.

100. Bhan A, Soleimani M and Mandal SS: Long noncoding RNA and cancer: A new paradigm. Cancer Res 77: 3965-3981, 2017.

101. Dragomir M, Chen B and Calin GA: Exosomal lncRNAs as new players in cell-to-cell communication. Transl Cancer Res 7 (Suppl 2): S243-S252, 2018.

102. Momen-Heravi F, Getting SJ and Moschos SA: Extracellular vesicles and their nucleic acids for biomarker discovery. Pharmacol Ther 192: 170-187, 2018.

103. Halvaei S, Daryani S, Eslami-S Z, Samadi T, Jafarbeik-Iravani N, Bakhshayesh TO, Majidzadeh-A K and Esmaeili R: Exosomes in cancer liquid biopsy: A focus on breast cancer. Mol Ther Nucleic Acids 10: 131-141, 2018

104. Hannafon BN, Trigoso YD, Calloway CL, Zhao YD, Lum DH, Welm AL, Zhao ZJ, Blick KE, Dooley WC and Ding WQ: Plasma exosome microRNAs are indicative of breast cancer. Breast Cancer Res 18: 90, 2016.

105. Shi W, Gerster K, Alajez NM, Tsang J, Waldron L, Pintilie M, Hui AB, Sykes J, P'ng C, Miller N, et al: MicroRNA-301 mediates proliferation and invasion in human breast cancer. Cancer Res 71: 2926-2937, 2011.

106. Ma F, Zhang J, Zhong L, Wang L, Liu Y, Wang Y, Peng L and Guo B: Upregulated microRNA-301a in breast cancer promotes tumor metastasis by targeting PTEN and activating Wnt/ß-catenin signaling. Gene 535: 191-197, 2014

107. Lettlova S, Brynychova V, Blecha J, Vrana D, Vondrusova M, Soucek P and Truksa J: MiR-301a-3p suppresses estrogen signaling by directly inhibiting ESR1 in ER $\alpha$ positive breast cancer. Cell Physiol Biochem 46: 2601-2615, 2018.

108. Mihelich BL, Dambal S, Lin S and Nonn L: miR-182, of the miR-183 cluster family, is packaged in exosomes and is detected in human exosomes from serum, breast cells and prostate cells. Oncol Lett 12: 1197-1203, 2016.

109. Sueta A, Yamamoto Y, Tomiguchi M, Takeshita T, Yamamoto-Ibusuki M and Iwase H: Differential expression of exosomal miRNAs between breast cancer patients with and without recurrence. Oncotarget 8: 69934-69944, 2017.

110. Rodriguez-Martinez A, de Miguel-Pérez D, Ortega FG, García-Puche JL, Robles-Fernández I, Exposito J, Martorell-Marugan J, Carmona-Sáez P, Garrido-Navas MDC, Rolfo C, et al: Exosomal miRNA profile as complementary tool in the diagnostic and prediction of treatment response in localized breast cancer under neoadjuvant chemotherapy. Breast Cancer Res 21: 21, 2019.

111. Stevic I, Müller V, Weber K, Fasching PA, Karn T, Marmé F, Schem C, Stickeler E, Denkert C, van Mackelenbergh M, et al: Specific microRNA signatures in exosomes of triple-negative and HER2-positive breast cancer patients undergoing neoadjuvant therapy within the GeparSixto trial. BMC Med 16: 179, 2018.

112. Joyce DP, Kerin MJ and Dwyer RM: Exosome-encapsulated microRNAs as circulating biomarkers for breast cancer. Int J Cancer 139: 1443-1448, 2016.

113. Eichelser C, Stückrath I, Müller V, Milde-Langosch K, Wikman H, Pantel K and Schwarzenbach H: Increased serum levels of circulating exosomal microRNA-373 in receptor-negative breast cancer patients. Oncotarget 5: 9650-9663, 2014.

114. Cuk K, Zucknick M, Madhavan D, Schott S, Golatta M, Heil J, Marmé F, Turchinovich A, Sinn P, Sohn C, et al: Plasma microRNA panel for minimally invasive detection of breast cancer. PLoS One 8: e76729, 2013.

115. Koldemir O, Özgür E and Gezer U: Accumulation of GAS5 in exosomes is a marker of apoptosis induction. Biomed Rep 6: 358-362, 2017.

116. Moon PG, Lee JE, Cho YE, Lee SJ, Jung JH, Chae YS, Bae HI, Kim YB, Kim IS, Park HY and Baek MC: Identification of developmental endothelial locus-1 on circulating extracellular vesicles as a novel biomarker for early breast cancer detection. Clin Cancer Res 22: 1757-1766, 2016.

117. Moon PG, Lee JE, Cho YE, Lee SJ, Chae YS, Jung JH, Kim IS, Park HY and Baek MC: Fibronectin on circulating extracellular vesicles as a liquid biopsy to detect breast cancer. Oncotarget 7 : 40189-40199, 2016

118. Higginbotham JN, Demory Beckler M, Gephart JD, Franklin JL, Bogatcheva G, Kremers GJ, Piston DW, Ayers GD, McConnell RE, Tyska MJ and Coffey RJ: Amphiregulin exosomes increase cancer cell invasion. Curr Biol 21: 779-786, 2011. 
119. Khan S, Bennit HF, Turay D, Perez M, Mirshahidi S, Yuan Y and Wall NR: Early diagnostic value of survivin and its alternative splice variants in breast cancer. BMC Cancer 14: 176, 2014

120. Melo SA, Luecke LB, Kahlert C, Fernandez AF, Gammon ST, Kaye J, LeBleu VS, Mittendorf EA, Weitz J, Rahbari N, et al: Glypican-1 identifies cancer exosomes and detects early pancreatic cancer. Nature 523: 177-182, 2015.

121. Rupp AK, Rupp C, Keller S, Brase JC, Ehehalt R, Fogel M, Moldenhauer G, Marmé F, Sültmann $\mathrm{H}$ and Altevogt P: Loss of EpCAM expression in breast cancer derived serum exosomes: Role of proteolytic cleavage. Gynecol Oncol 122: 437-446, 2011.

122. Lim LH and Pervaiz S: Annexin 1: The new face of an old molecule. FASEB J 21: 968-975, 2007.

123. Galindo-Hernandez O, Villegas-Comonfort S, Candanedo F, González-Vázquez MC, Chavez-Ocaña S, Jimenez-Villanueva X, Sierra-Martinez M and Salazar EP: Elevated concentration of microvesicles isolated from peripheral blood in breast cancer patients. Arch Med Res 44: 208-214, 2013.

124. Kooijmans SA, Vader P, van Dommelen SM, van Solinge WW and Schiffelers RM: Exosome mimetics: A novel class of drug delivery systems. Int J Nanomedicine 7: 1525-1541, 2012.

125. Kahlert $C$ and Kalluri R: Exosomes in tumor microenvironment influence cancer progression and metastasis. J Mol Med (Berl) 91: 431-437, 2013

126. Marleau AM, Chen CS, Joyce JA and Tullis RH: Exosome removal as a therapeutic adjuvant in cancer. J Transl Med 10: 134, 2012

127. Kumar D, Gupta D, Shankar S and Srivastava RK: Biomolecular characterization of exosomes released from cancer stem cells: Possible implications for biomarker and treatment of cancer. Oncotarget 6: 3280-3291, 2015.

128. Shen Y, Ye YF, Ruan LW, Bao L, Wu MW and Zhou Y: Inhibition of miR-660-5p expression suppresses tumor development and metastasis in human breast cancer. Genet Mol Res 16, 2017.

129. Zhang P, Zhou H, Lu K, Lu Y, Wang Y and Feng T: Exosome-mediated delivery of MALAT1 induces cell proliferation in breast cancer. Onco Targets Ther 11: 291-299, 2018.

130. Yeo RW, Lai RC, Zhang B, Tan SS, Yin Y, The BJ and Lim SK Mesenchymal stem cell: An efficient mass producer of exosomes for drug delivery. Adv Drug Deliv Rev 65: 336-341, 2013.

131. Rani S, Ryan AE, Griffin MD and Ritter T: Mesenchymal stem cell-derived extracellular vesicles: Toward cell-free therapeutic applications. Mol Ther 23: 812-823, 2015.

132. Ohno S, Takanashi M, Sudo K, Ueda S, Ishikawa A, Matsuyama N, Fujita K, Mizutani T, Ohgi T, Ochiya T, et al: Systemically injected exosomes targeted to EGFR deliver antitumor microRNA to breast cancer cells. Mol Ther 21: 185-191, 2013.

133. de Jong OG, Kooijmans SAA, Murphy DE, Jiang L, Evers MJW, Sluijter JPG, Vader P and Schiffelers RM: Drug delivery with extracellular vesicles: From imagination to innovation. Acc Chem Res 52: 1761-1770, 2019.

134. Iyengar P, Combs TP, Shah SJ, Gouon-Evans V, Pollard JW, Albanese C, Flanagan L, Tenniswood MP, Guha C, Lisanti MP, et al: Adipocyte-secreted factors synergistically promote mammary tumorigenesis through induction of anti-apoptotic transcriptional programs and proto-oncogene stabilization. Oncogene 22: 6408-6423, 2003.

135. Yao Y and Zhou Q: A novel antiestrogen agent Shikonin inhibits estrogen-dependent gene transcription in human breast cancer cells. Breast Cancer Res Treat 121: 233-240, 2010.

136. Cho JA, Yeo DJ, Son HY, Kim HW, Jung DS, Ko JK, Koh JS, Kim YN and Kim CW: Exosomes: A new delivery system for tumor antigens in cancer immunotherapy. Int J Cancer 114: 613-622, 2005.

137. Tan A, De La Peña H and Seifalian AM: The application of exosomes as a nanoscale cancer vaccine. Int J Nanomedicine 5: 889-900, 2010.

138. Wu CY, Du SL, Zhang J, Liang AL and Liu YJ: Exosomes and breast cancer: A comprehensive review of novel therapeutic strategies from diagnosis to treatment. Cancer Gene Ther 24 $6-12,2017$.
139. Kalluri R: The biology and function of exosomes in cancer. J Clin Invest 126: 1208-1215, 2016.

140. Skog J, Würdinger T, van Rijn S, Meijer DH, Gainche L, Sena-Esteves M, Curry WT Jr, Carter BS, Krichevsky AM and Breakefield XO: Glioblastoma microvesicles transport RNA and proteins that promote tumour growth and provide diagnostic biomarkers. Nat Cell Biol 10: 1470-1476, 2008.

141. Tanaka Y, Kamohara H, Kinoshita K, Kurashige J, Ishimoto T, Iwatsuki M, Watanabe M and Baba H: Clinical impact of serum exosomal microRNA-21 as a clinical biomarker in human esophageal squamous cell carcinoma. Cancer 119: 1159-1167, 2013.

142. Costa-Silva B, Aiello NM, Ocean AJ, Singh S, Zhang H, Thakur BK, Becker A, Hoshino A, Mark MT, Molina H, et al: Pancreatic cancer exosomes initiate pre-metastatic niche formation in the liver. Nat Cell Biol 17: 816-826, 2015

143. Castillo J, Bernard V, San Lucas FA, Allenson K, Capello M, Kim DU, Gascoyne P, Mulu FC, Stephens BM, Huang J, et al: Surfaceome profiling enables isolation of cancer-specific exosomal cargo in liquid biopsies from pancreatic cancer patients. Ann Oncol 29: 223-229, 2018.

144. Zhang P, Wang L, Fang Y, Zheng D, Lin T and Wang H: Label-free exosomal detection and classification in rapid discriminating different cancer types based on specific Raman phenotypes and multivariate statistical analysis. Molecules 24: pii: E2947, 2019.

145. Larssen P, Wik L, Czarnewski P, Eldh M, Löf L, Ronquist KG, Dubois L, Freyhult E, Gallant CJ, Oelrich J, et al: Tracing cellular origin of human exosomes using multiplex proximity extension assays. Mol Cell Proteomics 16: 502-511, 2017.

146. Wu D, Yan J, Shen X, Sun Y, Thulin M, Cai Y, Wik L, Shen Q, Oelrich J1, Qian X, et al: Profiling surface proteins on individual exosomes using a proximity barcoding assay. Nat Commun 10 : $3854,2019$.

147. Chen C, Zong S, Liu Y, Wang Z, Zhang Y, Chen B and Cui Y: Profiling of exosomal biomarkers for accurate cancer identification: Combining DNA-PAINT with machine-learning-based classification. Small 15: e1901014, 2019.

148. Shimomura A, Shiino S, Kawauchi J, Takizawa S, Sakamoto H, Matsuzaki J, Ono M, Takeshita F, Niida S, Shimizu C, et al: Novel combination of serum microRNA for detecting breast cancer in the early stage. Cancer Sci 107: 326-334, 2016.

149. Roccaro AM, Sacco A, Maiso P, Azab AK, Tai YT, Reagan M, Azab F, Flores LM, Campigotto F, Weller E, et al: BM mesenchymal stromal cell-derived exosomes facilitate multiple myeloma progression. J Clin Invest 123: 1542-1555, 2013.

150. Schwarzenbach $\mathrm{H}$ : The clinical relevance of circulating, exosomal miRNAs as biomarkers for cancer. Expert Rev Mol Diagn 15: 1159-1169, 2015

151. Takahashi Y, Nishikawa M, Shinotsuka H, Matsui Y, Ohara S, Imai $\mathrm{T}$ and Takakura Y: Visualization and in vivo tracking of the exosomes of murine melanoma B16-BL6 cells in mice after intravenous injection. J Biotechnol 165: 77-84, 2013.

152. Smyth T, Kullberg M, Malik N, Smith-Jones P, Graner MW and Anchordoquy TJ: Biodistribution and delivery efficiency of unmodified tumor-derived exosomes. J Control Release 199: $145-155,2015$

153. Bala S, Csak T, Momen-Heravi F, Lippai D, Kodys K, Catalano D, Satishchandran A, Ambros V and Szabo G: Biodistribution and function of extracellular miRNA-155 in mice. Sci Rep 5: 10721, 2015.

154. Tian T, Wang Y, Wang H, Zhu Z and Xiao Z: Visualizing of the cellular uptake and intracellular trafficking of exosomes by live-cell microscopy. J Cell Biochem 111: 488-496, 2010.

155. Grange C, Tapparo M, Bruno S, Chatterjee D, Quesenberry PJ, Tetta C and Camussi G: Biodistribution of mesenchymal stem cell-derived extracellular vesicles in a model of acute kidney injury monitored by optical imaging. Int J Mol Med 33: 1055-1063, 2014. 